\title{
Stepwise Oxidations Play Key Roles in the Structural and Functional Regulations of DJ-1
}

\author{
In-Kang Song ${ }^{1}$, Mi-Sun Kim ${ }^{1}$, James E. Ferrell Jr. ${ }^{2}$, Dong-Hae Shin ${ }^{1^{*}}$, Kong-Joo Lee ${ }^{1^{*}}$
}

${ }^{1}$ College of Pharmacy and Graduate School of Pharmaceutical Sciences, Ewha Womans University,

Seoul, Korea 03760, ${ }^{2}$ Department of Chemical and Systems Biology, Stanford University School of Medicine, Stanford, Ca 94305-5174, USA

*Corresponding author: Kong-Joo Lee, Tel: +82-2-3277-3038, Fax: +82-2-3277-3760: e-mail:

\section{kj1@ewha.ac.kr;}

Dong-Hae Shin, dhshin55@ewha.ac.kr

Keywords - DJ-1, redox-sensitive protein, cysteine oxidative modifications, intra-disulfide bond, hydrogen-deuterium exchange mass spectrometry (HDX-MS), stepwise oxidation 


\begin{abstract}
DJ-1 is known to play neuroprotective roles by eliminating reactive oxygen species (ROS) as an antioxidant protein. However, the molecular mechanism of DJ-1 function has not been well elucidated. This study explored the structural and functional changes of DJ-1 in response to oxidative stress. We found that Cys46 is also reactive cysteine residue in DJ-1, which was identified employing an NPSBB chemical probe that selectively reacts with redox sensitive cysteine sulfhydryl. Peroxidatic Cys46 readily formed an intra-disulfide bond with resolving Cys53, which was identified with nanoUPLCESI-q-TOF tandem mass spectrometry (MS/MS) employing DBond algorithm under the non-reducing condition. We also found that Cys46-Cys53 disulfide crosslinking affects the oxidative state of the third Cys106, which shows the crosstalk among three cysteine residues of DJ-1. Furthermore, we demonstrated that DJ-1 C46A mutant, not forming Cys46-Cys53 intra-disulfide bond, lost structural stability of DJ-1 employing hydrogen/deuterium exchange-mass spectrometry (HDX-MS) analysis. All three Cys mutants lost antioxidant activities in SN4741 cell, a dopaminergic neuronal cell, unlike wild type DJ-1. These findings suggest that DJ-1 regulates its structure and activities by concerted oxidative modifications of three cysteine residues. These studies broaden the understanding of regulatory mechanisms of DJ-1 that operate under oxidative conditions.
\end{abstract}

\title{
Introduction
}

Pathological feature of Parkinson's disease (PD) is the selective degeneration of dopaminergic neurons, controlling key neurotransmitters related to movement, cognition, learning, and mood in the Substantia Nigra pars compacta (SNpc) of the human brain [1]. Mutations in several genes including DJ-1, $\alpha$-synuclein, Parkin, Pink1, LRRK2 and UCH-L1 cause autosomal recessive PD [2] and increased ROS levels were observed in SNpc of sporadic PD patients [3]. Of these genes, several mutations in DJ-1 encoding the PARK7 gene, are associated with early onset familial PD [4]. Since then, huge amounts of effort have been put to understand the contribution of DJ-1 to PD pathology. DJ-1 consisted 
of 189 amino acids, is evolutionary well conserved and ubiquitous small protein abundantly present in brain, especially in the Substantia Nigra [5]. Overexpression of DJ-1 results in neuronal cell protection against oxidative stress, while DJ-1 deficiency precedes oxidative stress induced cell death in cultured neuroblastoma cells and drosophila animal models [6-9]. In addition to antioxidant function of DJ-1, several different functions including transcriptional regulation and glyoxalase/deglycase activities have been assigned to DJ-1, which should be further studied for understanding the cause of these functions to $\mathrm{PD}[10]$.

L166P mutant of DJ-1, known mutant showing parkinsonian phenotype [11], is poorly folded [12] and lost its functions on eliminating free radicals and protecting cells [13], and oxidized DJ-1 is found in the brains of idiopathic PD individuals $[14,15]$. So, structural changes of DJ-1 in response to mutations and oxidative stress have been intensively studied. DJ-1 has a flavodoxin-like Rossmannfold containing a parallel $\beta$-sheet, and exists as a homodimer in crystal [16]. Its $\mathrm{N}$-terminal sequence is necessary for the localization of DJ-1 to mitochondria [17]. The G-helix and kink portions of the Cterminal region are critical for the stability and redox-signaling of DJ-1 [18]. Analyses of the crystal structures of DJ-1 elucidate Cys106 residues at the sharp turn between a $\beta$-strand and an $\alpha$-helix called the "nucleophile elbow". Cys106 has energetically distorted angle, which raises reactivity of Cys106 by decreasing $\mathrm{pKa}$ [12] and by interacting with the protonated Glu18 residue via a hydrogen bond [19]. Oxidized DJ-1 at Cys106 to sulfenic and sulfinic acid and PD-associated known mutants (E64D, M26I, A104T, D149A) except L166P mutant demonstrate the modest structural changes compare to WT DJ1 except subtle changes in weak chemical binding at residues [20-22]. In order to determine the dynamic structural changes of DJ-1 in response to oxidative stress, a hydrogen/deuterium exchange-mass spectrometry (HDX-MS) method was employed to fill a lack of dynamic changes absent in X-ray crystal structures [23]. In previous works with HDX-MS, we identified similar oxidative regulation in Nm23H1 (NDPK-A) [24], peroxiredoxin 2 [25] and human secretagogin (hSCGN) by $\mathrm{Ca}^{2+}$ binding [26]. Hexameric Nm23-H1/NDPK-A, a tumor metastasis suppressor, is readily lost enzymatic activity by 
oxidizing Cys109 to sulfonic acid, even it is not active site, by oxidative stress [27], although Cys4 is the most redox sensitive residue. Single reactive cysteine can be easily oxidized and modified to be sulfenic acid (-SOH), sulfinic acid $\left(-\mathrm{SO}_{2} \mathrm{H}\right)$ and sulfonic acid $\left(-\mathrm{SO}_{3} \mathrm{H}\right)$. In addition, it contributes to form a disulfide bond together with adjacent resolving cysteine which is not reactive [28]. It has been found that reactive Cys4 forms intra-disulfide bond with Cys 145, the resolving cysteine. It turns out that Cys4Cys145 intra-disulfide bonds triggers a large conformational change that destabilizes the hexameric state which makes Cys109 oxidized to sulfonic acid. C4A and C145A mutants cannot oxidize Cys109 and are always active as well as C109A [24]. This indicates stepwise oxidation is one way of oxidative regulation of proteins. In addition to stepwise oxidation, oxidized proteins can be readily degraded in proteasome by oxidation induced structural change makes the protein be ubiquitinated in redox sensitive proteins including peroxiredoxin and DJ-1 etc [25]. Secretagogin, a hexa EF-hand calcium binding protein functioning in insulin secretion in pancreatic beta-cells, induces the structural change by calcium binding, which triggers the formation of functional dimer via inter-disulfide crosslinking [26]. These examples suggest the stepwise regulation combining oxidation with oxidation, ubiquitination and phosphorylation [29].

DJ-1 is a redox-sensitive protein easily oxidized and degraded by oxidative stress [25]. Because antioxidant proteins have reactive Cys residues with redox capacity, we focused the property of cysteine residues in DJ-1. There are three cysteines in DJ-1; Cys46, Cys53 and Cys106. Orthologous analysis demonstrated that Cys106 [30] and Cys46 are well conserved in every species from C. elegans to $H$. sapiens. However, Cys53 is conserved in mammalian only (Fig. 1A, Supplementary Table 1). In general, evolutionary well-conserved residues have a tendency to be transmitted to a lineage of life and can play important roles in effective protein folding, stability and function [31]. Of these, Cys106 is known as the most readily modified residue by oxidation to sulfinic acid [30,32-34], which shifts DJ-1 to the mitochondria, thereby protecting neurons from oxidative stress. To date, most research on DJ-1 has been focused on Cys106, but recently the importance of Cys46 and Cys53 has also been raised. Cys46 and Cys53, but not Cys106, are susceptible to S-nitrosylated and Cys46 is involved in the dimerization 
of DJ-1[35]. Cys53 and Cys106 are known to react with dopamine to form adducts [36], and Cys53 are known to be needed for dimer formation because they are near the dimer interface [37]. However, it is not still possible to explain how DJ-1 can sense oxidative stress, how DJ-1 protects cells from oxidative stress, and how DJ-1 contribute PD pathogenesis. Here, we focus how DJ-1 is modified in response to oxidative stress and how Cys mutants induce the structural changes and regulate the cellular functions.

In the present study, using a novel specific biotin-labeling chemical probe, which reacts with redoxsensitive Cys-SH residues [38] and HDX-MS [23], we identified that the reactive Cys residue in DJ-1 is Cys46, and found that C46A mutant display profound structural defects like L166P DJ-1 mutant. We focused on oxidative modifications and structural changes of three DJ-1 Cys mutants and suggest that Cys46 residue is critical to maintain stable structure and Cys46-Cys53 intra-disulfide bond regulates the oxidative status of Cys106 in concerted way. We further demonstrated that all three DJ-1 mutants (C46A, C53A, C106A) abolished the protective functions against oxidative stress in neuronal cell. These results reveal that all three cysteine residues of DJ-1 are indispensable for maintaining the structure, regulation process and function as an antioxidant protein.

\section{Materials and Methods}

\section{Cell culture and transfection}

Human cervical carcinoma HeLa cells from ATCC (VA, USA) were cultured in Eagle's minimum essential medium (EMEM) supplemented with $10 \%$ fetal bovine serum (FBS), $100 \mu \mathrm{g} / \mathrm{mL}$ streptomycin and 100 units $/ \mathrm{mL}$ penicillin $\mathrm{G}$ at $37^{\circ} \mathrm{C}$ in an atmosphere of $5 \% \mathrm{CO}_{2}-95 \%$ air. SN4741 dopaminergic neuronal cell was cultured at $33^{\circ} \mathrm{C}$ with $5 \% \mathrm{CO}_{2}$ in $\mathrm{RF}$ medium containing DMEM supplemented with $10 \% \mathrm{FBS}, 1 \%$ glucose, $100 \mu \mathrm{g} / \mathrm{mL}$ streptomycin and $100 \mathrm{units} / \mathrm{mL}$ penicillin $\mathrm{G}$, and L-glutamine [47]. For transient overexpression of specific proteins in HeLa cells and SN4741 DJ-1 KO cells, cells were transfected using LT-1 and analyzed $48 \mathrm{~h}$ later. 


\section{Plasmids}

Human DJ-1 were cloned into pFlag-CMV2 and pGEX-4T-1 vectors. Cys to Ala mutants of Flag-tagged DJ-1 were using QuikChange II Site-Directed Mutagenesis kit (Agilent Technologies, USA) according to the manufacturer's protocol. The primers used for mutagenesis are as follows: C46A_s, 5'-GAA AAG ACC CAG TAC AGG CTA GCC GTG ATG TGG TC-3'; C46A_as, 5'-GAC CAC ATC ACG GCT AGC CTG TAC TGG GTC TTT TC-3'; C53A_s, 5'-CCG TGA TGT GGT CAT TGC TCC TGA TGC CAG CCT TG-3'; C53A_as, 5'-CAA GGC TGG CAT CAG GAG CAA TGA CCA CAT CAC GG-3'; C106A_s, 5'-CCT GAT AGC CGC CAT CGC TGC AGG TCC TAC TGC TC-3'; C106A_as, 5'-GAG CAG TAG GAC CTG CAG CGA TGG CGG CTA TCA GG-3'. All plasmids were confirmed by DNA sequencing.

\section{Purification of Recombinant proteins}

A pGEX-4T-1 plasmid carrying human DJ-1 gene was expressed in BL21 (DE3) E.coli cells. Bacteria were cultured in $\mathrm{LB}$ medium at $37^{\circ} \mathrm{C}$, and recombinant fusion protein production was induced with 0.25 $\mathrm{mM}$ were isopropyl- $\beta$-D-thiogalactopyranoside (IPTG). After $4 \mathrm{~h}$ of additional incubation at $37^{\circ} \mathrm{C}$, the cells were harvested and lysed by vortexing with lysozyme containing lysis buffer (lysozyme, protease inhibitor, triton X-100 in PBS (140 mM NaCl, $\left.2.7 \mathrm{mM} \mathrm{KCl}, 10 \mathrm{mM} \mathrm{Na}_{2} \mathrm{HPO}_{4}, \mathrm{pH} 7.4\right)$ ) on ice and sonicated. Soluble protein fraction was recovered by centrifugation at $13,000 \mathrm{~g}$ for $30 \mathrm{~min}$ at $4^{\circ} \mathrm{C}$. GSTfused recombinant proteins in supernatant were purified by chromatography on a glutathione-agarose column followed by washing, and equilibration by elution buffer $(140 \mathrm{mM} \mathrm{NaCl}, 2.7 \mathrm{mM} \mathrm{KCl}, 10 \mathrm{mM}$ $\mathrm{Na}_{2} \mathrm{HPO}_{4}, \mathrm{pH}$ 7.4). To cleave DJ-1 from GST-DJ-1, the beads were incubated overnight at RT with thrombin in DJ-1 elution buffer. After $16 \mathrm{~h}$, purified DJ-1 was eluted and protein concentration was quantified with the BCA protein assay.

\section{NPSB-B labeling}

Methods for the labeling of reactive cysteine residues by NPSB-B were previously reported [38]. Briefly, 
$2 \mu \mathrm{g}$ of recombinant DJ-1 was pre-incubated with various concentration of $\mathrm{H}_{2} \mathrm{O}_{2}$ at $37^{\circ} \mathrm{C}$ for $1 \mathrm{~h}$ followed by incubation with NPSB-B (final concentration $1 \mathrm{mM}$ ) at RT for $2 \mathrm{~h}$. Proteins were separated by $12 \%$ SDS-PAGE and transferred to PVDF membranes. Labeled proteins were detected by streptavidin-HRP. Amount of total loaded protein was detected by Coomassie staining.

\section{Identification of Cys modifications employing nanoUPLC-ESI-q-TOF tandem MS}

Recombinant WT and mutant proteins $(2 \mu \mathrm{g})$ and over-expressed Hela cell with DJ-1 WT and mutants were incubated with various concentrations of $\mathrm{H}_{2} \mathrm{O}_{2}$ at $37^{\circ} \mathrm{C}$ for $1 \mathrm{~h}$ followed by separation by SDSPAGE under non-reducing and reducing condition. In order to prevent oxidation during sample preparation, alkylating agent N-ethylmaleimide (NEM) was treated in several indicated experiments. All experiments were triplicated. Gel bands of differentially expressed proteins were destained and digested with trypsin, and the resulting peptides were extracted as previously described [58]. Peptides were separated using trap column cartridge, injected into C18 reversed-phase analytical column with integrated electrospray ionization PicoTip $^{\mathrm{TM}}$ using nanoAcquity ${ }^{\mathrm{TM}}$ UPLC/ESI/q-TOF MS/MS $\left(\right.$ SYNAPT $^{\mathrm{TM}}$ G2Si; Waters Co.). Peptide solutions were injected into column and eluted by linear gradient of 5-40\% buffer B (ACN/formic acid; 100:0.1, v/v) with buffer A (Water/formic acid; 100:0.1, $\mathrm{v} / \mathrm{v}$ ) over $60 \mathrm{~min}$. Mass spectrometer was programmed to record scan cycles composed of one MS scan followed by MS/MS scans of the 10 most abundant ions in each MS scan.

\section{Search parameters and acceptance criteria for MS data}

Pkl files were generated using ProteinLynx global server 2.3 (Waters Co.,). Peaklists were searched against DJ-1 FASTA file (Uniprot accession no. Q99497) using Mascot (version 2.2.06, Boston, USA), $\operatorname{MOD}^{\mathrm{i}}[59]$ and Modplus (https://prix.hanyang.ac.kr). For Cys oxidative modification search of samples, oxidation, dioxidation and trioxidation of Cys, $\mathrm{Cys}_{-} \mathrm{SO}_{2}-\mathrm{SH}$, conversion of Cys to Ser, and acrylamide adduct propionamide of Cys were used as variable modifications. Mass tolerance for precursor ions was $\pm 0.5 \mathrm{Da}$ and mass tolerance for fragment ions was $\pm 0.5 \mathrm{Da}$ because the error value of MS was about 0.01. Significant matches were sorted by the threshold indicated by Mascot probability analysis, and 
matches with probability-based Mowse score $\mathrm{P}<0.05$ (and expectation value of 0.05 ) were considered significant. Ions score was calculated as $-10 \mathrm{x} \log (\mathrm{P})(\mathrm{P}$ : the probability that the observed match is a random event) and automatically provided as Mascot result. Regarding the protein identification result, the best match with the highest score amongst identified results was used as the identification result for the spot. PTM results were verified not just by score threshold, but by checking each spectrum carefully. MS peaks in Supplementary Fig. 3 were generated by MOD ${ }^{i}$ spectrum viewer [59].

\section{Disulfide analysis of DJ-1 using nanoUPLC-ESI-q-TOF tandem MS and DBond algorithm}

Peptides resulting from trypsin-digested protein (for C46A, Glu-C and trypsin-) in non-reducing gel were resuspended in $10 \%$ acetonitrile containing $0.1 \%$ formic acid and analyzed using nanoAcquity ${ }^{\mathrm{TM}}$ $\mathrm{UPLC}^{\mathrm{TM}} / \mathrm{ESI} / \mathrm{MS}$ (SYNAPT ${ }^{\mathrm{TM}} \mathrm{G} 2 \mathrm{Si}$, Waters Co. UK) as described previously [58]. Tandem MS (MS/MS) spectra were matched against DJ-1 fasta (Uniprot accession no. Q99497) using DBond algorithm (https://prix.hanyang.ac.kr) [40]. For recombinant protein sample, mass tolerance for precursor ions was $\pm 0.2 \mathrm{Da}$ and mass tolerance for fragment ions was $\pm 0.2 \mathrm{Da}$ and for Hela cell sample, mass tolerance for precursor ions was $\pm 0.5 \mathrm{Da}$ and mass tolerance for fragment ions was \pm 0.5 Da due to low intensity). DBond score was calculated by byIonScore, bondScore and sulfurScore and automatically provided as DBond result. For recombinant protein sample, the sample intensity was high, only scores above 50 were taken. MS peaks in Figs. 2B, 6C, Supplementary Fig. 3 and 6 were generated by $\mathrm{MOD}^{\mathrm{i}}$ spectrum viewer [59].

\section{HDX-Hydrogen/deuterium exchange mass spectrometry (HDX-MS)}

Methods for the HDX-MS were previously reported [26]. DJ-1 protein $(1 \mu \mathrm{g})$ was diluted 9-fold with labeling buffer (10 mM HEPES in $\left.\mathrm{D}_{2} \mathrm{O}, \mathrm{pH} 7.4\right)$ and incubated at $25^{\circ} \mathrm{C}$ for $10,60,300,1800$, or $10800 \mathrm{~s}$. Deuterium labeling reaction was quenched by $2.5 \mathrm{mM}$ tris (2-carboxyethyl) phosphine (TCEP), formic acid, $\mathrm{pH}$ 2.3. For protein digestion, $1 \mu \mathrm{g}$ of porcine pepsin was added to each quenched protein sample and incubated on ice for 3 min before injection. Peptic peptides were desalted on C18 trap column cartridge (Waters, UK) and gradient eluted from $8 \% \mathrm{CH}_{3} \mathrm{CN}$ to $40 \% \mathrm{CH}_{3} \mathrm{CN}, 0.1 \%$ formic acid on 
$100 \mu \mathrm{m}$ i.d. $\times 100 \mathrm{~mm}$ analytical column, $1.7 \mu \mathrm{m}$ particle size, BEH130 C18, (Waters, UK) for $7 \mathrm{~min}$. The trap, analytical column and all tubing were immersed in ice bath to minimize deuterium backexchange. Gradient chromatography was performed at a flow rate $0.5 \mu \mathrm{L} / \mathrm{min}$ and was sprayed on line to nanoAcquity ${ }^{\mathrm{TM}} / \mathrm{ESI} / \mathrm{MS}$ (SYNAPT ${ }^{\mathrm{TM}} \mathrm{HDMS}^{\mathrm{TM}}$ ) (Waters, UK). The extent of deuterium incorporation was monitored by increase in mass of isotope distribution for each identified peptide, and calculated using Microsoft Excel. Each experiment was performed in triplicate.

\section{Circular dichroism (CD)}

Circular dichroism (CD) and thermal denaturation were recorded in buffer containing $137 \mathrm{mM} \mathrm{NaCl}$, $2.7 \mathrm{mM} \mathrm{KCl}$ and $10 \mathrm{mM} \mathrm{Na}_{2} \mathrm{HPO}_{4}$ at pH 7.4 using a JASCO J-1500 spectropolarimeter (Jasco,Tokyo, Japan). The concentration of protein solution was $0.25 \mathrm{mg} / \mathrm{mL}$ for $\mathrm{CD}$ experiments. Monitoring of protein thermal denaturation was performed in temperature range $20-90^{\circ} \mathrm{C}$, increasing the temperature at the rate of $1^{\circ} \mathrm{C} / \mathrm{min}$. After $1 \mathrm{~min}$ of equilibration at each temperature, ellipticity was measured at 222 $\mathrm{nm}$.

\section{Protein denaturation induced by GdnHCl}

Protein unfolding induced by guanidinium hydrochloride $(\mathrm{GdnHCl})$ was performed by incubating WT and mutants proteins in PBS containing various concentrations of $\mathrm{GdnHCl}(\mathrm{pH}$ 7.4) ranging from 0 to 2.0 M $16 \mathrm{~h}$ at $25^{\circ} \mathrm{C}$. Final protein concentration was $0.2 \mathrm{mg} / \mathrm{mL}$. Unfolded samples were incubated with 8-anilinonaphtalene-1-sulfonic acid (ANS) for fluorescence measurements to monitor structural changes induced by unfolding.

\section{Co-immunoprecipitation}

HeLa cells were seeded at a density of $7.5 \times 10^{5}$ cells/ $100-\mathrm{mm}$ plate and grown for $24 \mathrm{~h}$. Control plasmid pFlag CMV vector, and plasmids carrying wild-type (WT) and Cys mutants (C46A, C53A and C106A) of DJ-1 were delivered into cells respectively using LT-1 transfection reagent. At $24 \mathrm{~h}$ post-transfection, 
cells were washed twice with $2 \mathrm{~mL}$ Hanks' Balanced Salt Solution (HBSS) to remove serum. Cells were treated with 0 or $0.5 \mathrm{mM}$ of $\mathrm{H}_{2} \mathrm{O}_{2}$ in $\mathrm{HBSS}$ for $1 \mathrm{~h}\left(37^{\circ} \mathrm{C}, 5 \% \mathrm{CO}_{2}\right)$, then lysed in IP lysis buffer $(50$ $\mathrm{mM}$ Tris-Cl, $\mathrm{pH}$ 7.4, $150 \mathrm{mM} \mathrm{NaCl}, 1 \mathrm{mM}$ EDTA, 0.5\% NP40, pH 7.4) supplemented with protease inhibitor mixture (Sigma) and phosphatase inhibitors (2.5 $\mathrm{mM} \mathrm{Na}_{3} \mathrm{VO}_{4}$ and $\left.2.5 \mathrm{mM} \mathrm{NaF}\right)$. Cells were passed 31-gauge syringe 10 times and centrifuged at 12,000 rpm for $10 \mathrm{~min}$. Supernatant was immunoprecipitated with anti-Flag antibody for $2 \mathrm{~h}$ and then with protein $\mathrm{G}$ Sepharose beads for $1 \mathrm{~h}$ at $4^{\circ} \mathrm{C}$. Beads were washed three times with $1 \mathrm{~mL}$ of lysis buffer and additionally twice with $1 \mathrm{~mL}$ of lysis buffer without detergent. Immune complex was solubilized in SDS gel sample buffer, separated on SDS-PAGE, and analyzed by silver staining and Western blot analysis.

\section{DCF-DA staining}

Cellular ROS levels were measured using fluorescent dye, 2', 7' -dichlorodihydrofluorescein diacetate (CM- $\mathrm{H}_{2}$ DCFDA) (Molecular Probes: OR, USA). SN4741 DJ-1 KO cells were incubated with $0 \mathrm{mM}$ or $0.5 \mathrm{mM} \mathrm{H}_{2} \mathrm{O}_{2}$ in $\mathrm{HBSS}$ at $33^{\circ} \mathrm{C}$ for $20 \mathrm{~min}$. For flow cytometry, cells were washed with cold PBS, and treated with $2 \mu \mathrm{M} \mathrm{CM}-\mathrm{H}_{2}$ DCFDA in $\mathrm{HBSS}$ at $33^{\circ} \mathrm{C}$ for $15 \mathrm{~min}$ in dark. Cells were collected by trypsinizing briefly and incubated in ice as pellet. The pellets was straightly suspended into buffer, and cellular ROS was immediately measured using FACSCalibur flow cytometer (BD Biosciences: NJ, USA). 10,000 cells were analyzed for each sample. To quantify log-amplified fluorescence which is emitted by cells, geometric mean (Geo Mean) of fluorescence intensity as well as median value for fluorescent peak was calculated by statistical analysis of BD CellQuest software.

\section{Antibodies}

Antibodies used in this study were: Flag (Sigma), $\beta$-actin (Santa Cruz), pERK(T202/Y204), ERK (Abcam) and DJ-1 (Ab frontier).

\section{Cell proliferation assay}

DJ-1 KO SN4741 cells were transiently transfected with Flag-DJ-1 WT and Cys mutants were 
incubated at 0 or $0.5 \mathrm{mM} \mathrm{H}_{2} \mathrm{O}_{2} 2 \mathrm{~h}$ at $33^{\circ} \mathrm{C}$. Cells were trypsinized and seeded at a density 2,500 cells in 96-well RTCA E-plate. For real-time cell analyzer analysis, cell growth was real time monitored under xCELLigence RTCA SP system (Acea Biosciences, Inc.).

\section{Results}

\section{Cys46 of DJ-1 is the reactive cysteine residue}

In order to investigate the properties of Cys46 and Cys53 together with already well-known Cys106, the reactivity of these cysteines was examined using recombinant WT and Cys mutant proteins. They were incubated with various concentrations of $\mathrm{H}_{2} \mathrm{O}_{2}$ in $1 \mathrm{~h}$ and then labeled with NPSB-B, a novel specific biotin-labeling chemical probe, which reacts with redox-sensitive Cys-SH residues [38]. As shown in Fig. 1B, WT DJ-1 has a highly reactive cysteine residue, which is readily labeled with NPSBB. The labeling decreased after oxidation in a $\mathrm{H}_{2} \mathrm{O}_{2}$-dose-dependent manner. The result indicates the presence of redox sensitive cysteine in DJ-1. The labeling result with C53A and C106A mutants also showed that the level of labeling with NPSB-B on both mutants was comparable with that of WT. In contrast, C46A mutant could not be well labeled with NPSB-B. The result indicates that Cys46 is the most redox sensitive Cys residue like Cys106. However, there is an increased labeling level detected on Cys106 mutant at $0.1 \mathrm{mM} \mathrm{H} \mathrm{H}_{2} \mathrm{O}_{2}$. This indicates that the reactivity of Cys46 increases as the concentration of $\mathrm{H}_{2} \mathrm{O}_{2}$ increases in the absence of $\mathrm{C} 106$, which requires further study. The result was corroborated by detecting labeled peptides at Cys46 with NPSB-1 which is a non-biotin probe with combining nanoUPLC-ESI-q-TOF mass spectrometry with Mascot algorithm. Tandem mass spectrum of the identified NPSB-1 labeling in Cys46 residue of WT DJ-1 ${ }^{33}$ VTVAGLAGKDPVQCSR ${ }^{48}$ $(\mathrm{m} / \mathrm{z}=890.4360 \mathrm{Da}, \mathrm{z}=2, \Delta=+179.02 \mathrm{Da}))$ is shown in Fig. 1C. These results suggest that Cys46 residue is the most reactive cysteine in DJ-1. 


\section{Cys46 and Cys53 form an intra-disulfide bond in vitro}

Since highly reactive Cys46 does not undergo various oxidation [39], it is possible to form a disulfide bond. To investigate whether Cys46 could form a disulfide bond, we examined the electrophoretic mobility of WT and mutant DJ-1s on SDS-PAGE with or without 2-mercaptoethanol ( $\beta$-ME) (Fig. 2A). WT and the C106A mutant were down-shifted under non-reducing conditions and returned to their original position under reducing conditions. The result indicated the presence of the same intra-disulfide bond in WT and C106A mutant considering the consistent pattern depending on $\mathrm{H}_{2} \mathrm{O}_{2}$ concentration. On the other hand, C46A and C53A mutants were mainly in the same position corresponding to a monomeric form in SDS-PAGE both under reducing and non-reducing conditions. In order to confirm that the down-shifted band formed an intra-disulfide bond, WT and C46A mutant were incubated with a reducing agent, 1,4-Dithiothreitol (DTT), by concentration, and only WT was reduced as the DTT concentration increased, confirming that intra-disulfide was released (Supplementary Fig. 1). These results suggested that $\mathrm{C} 46 \mathrm{~A}$ and $\mathrm{C} 53 \mathrm{~A}$ mutants do not form an intra-disulfide bond. It is worthwhile to mention that C46A mutant also forms a trimeric form and further aggregates with even higher molecular weight under $1 \mathrm{mM} \mathrm{H}_{2} \mathrm{O}_{2}$. C53 A mutant was found to form a trimer of which the amount is proportional to $\mathrm{H}_{2} \mathrm{O}_{2}$ concentration.

In order to validate these results with direct recognition of intact disulfide bonds, we identified the disulfide bond in DJ-1 employing nanoUPLC-ESI-q-TOF mass spectrometry and DBond, a disulfide searching algorithm [40]. Tandem MS spectra have confirmed the presence of intra-disulfide bond between Cys46 and Cys53 in the main band of WT sample after tryptic digestion

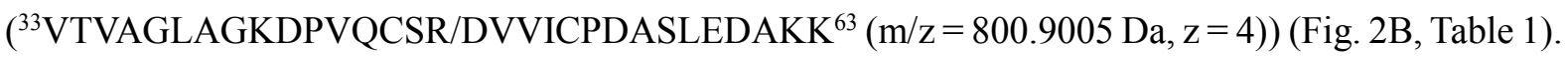
Intriguingly, C46A and C53A mutants lacking Cys46-Cys53 disulfide bond showed new disulfide bonds formed by Cys53-Cys106 (Supplementary Table 2) and Cys46-Cys106 (Supplementary Fig. 2, Table 1), respectively under oxidative stress, although scores are low in oxidized samples. The results show that DJ-1 is oxidized to form intra-disulfide bond primarily by Cys46 with Cys53, but three cysteine 
residues also seemed to influence each other's oxidation states.

\section{Each cysteine influenced on the oxidation state of other cysteines with different modifications}

The influence among three cysteines of DJ-1 has been investigated and analyzed by examining oxidative modifications of Cys residues in WT and three Cys mutants employing nanoUPLC-ESI-qTOF tandem MS combining Mascot search algorithm. Sulfhydryl modifications such as sulfenic, sulfinic and sulfonic acids together with various oxidative conversion of cysteine to dehydroalanine (DHA), serine or Cys-SO $\mathrm{S}_{2}$-SH resulting from breakdown of newly discovered thiosulfonate [41, 42] have been thoroughly examined in monomeric bands of $\mathrm{H}_{2} \mathrm{O}_{2}$ untreated samples appeared on reducing SDS-PAGE in Fig. 2A. The list of peptides containing each cysteine modification is shown in Fig. 3A. Cys106 was oxidized and modified into various oxidative forms (Fig. 3B); sulfinic acid $\left(-\mathrm{SO}_{2} \mathrm{H}, \Delta \mathrm{m}=\right.$ $+32 \mathrm{Da})$, sulfonic acid $\left(-\mathrm{SO}_{3} \mathrm{H}, \Delta \mathrm{m}=+48 \mathrm{Da}\right)$ and thiosulfonic acid $\left(-\mathrm{SO}_{2}-\mathrm{SH}, \Delta \mathrm{m}=+64 \mathrm{Da}\right)$. In WT, Cys106 was detected as sulfinic acid, an active form found in many cysteine residues. However, Cys106s in C46A and C53A mutants were more oxidized to sulfinic acid and significantly further oxidized to sulfonic acid, an irreversibly oxidized form. These results indicate that Cys106s in C46A and $\mathrm{C} 53 \mathrm{~A}$ mutants are more oxidized than that in WT.

Cys46 residues in WT, C53A and C106A are not oxidized except only one sulfonic acid in WT (Fig. 3C). Cys53s were slightly oxidized in WT, but more oxidized to sulfenic, sulfinic and sulfonic acid in C106A and further oxidized to sulfonic acid in C46A than those in WT (Fig. 3D). The results indicate that Cys106 is kept in sulfinic acid in WT, but is more oxidized to sufonic acid in mutant not forming disulfide bond. This suggests that one Cys mutation affects oxidative modifications of the other Cys residues.

\section{Intra-disulfide bond between Cys46-Cys53 in DJ-1 plays an important role in its structure}

Consistent with the results from the above experiments, Cys46 and Cys53 appear at a distance of $11.54 \AA$ in the X-ray crystal structure of human DJ-1 treated with DTT [43]. However, since both are 
on a flexible loop, it is possible they crosslink to form an intra-disulfide bond. (Fig. 4C). In the case of C46A mutant, a large conformational change should be happened to form Cys53-Cys106 intra-disulfide bond (Supplementary Table 2) due to a distant location of Cys53 and Cys106 with a distance of 23.08 Å. To investigate the influence of Cys46-Cys53 intra-disulfide bond on structural stability of DJ-1, we conducted HDX-MS analysis of WT and C46A mutant. We mapped DJ-1 sequence onto the structure deduced from X-ray crystallographic studies of $H$. sapiens DJ-1 (PDB ID code 4KRW) with chimera [44] and used this structure to display the results of the HDX-MS studies. H/D exchange rates of WT and C46A mutant were compared in each peptic digested peptide (Fig. 4A, Supplementary Table 3). Combined stitching $\mathrm{H} / \mathrm{D}$ exchange ratios of peptic peptide showed the diagram of whole protein shown in Fig. 4B and overlay of differential HDX data between WT and C46A mutant onto the structures of human DJ-1 in Fig. 4C. The peptide MS coverage was $100 \%$. This study revealed the differences between WT and C46A mutant with respect to deuterium incorporation rates in specific regions of protein. In most areas, C46A mutant exhibited higher deuterium exchange than WT. This indicates that C46A mutant is structurally dynamic and more exposed to solvent. In particular, the peptide comprising Cys106 residue (a.a 104-112) identified as involved in active site had higher deuterium exchange. As well as, deuterium exchange levels of peptides nearby Cys106 in tertiary structure also increased in C46A mutant. Cys106 is adjacent to Glu18 and His126. The former depresses pKa of Cys106 and modulates the reactivity of Cys106 [19], and the latter is member of catalytic diad with Cys106 in DJ1 superfamily [34]. In HDX-MS analysis, peptides containing regions around Glu18 (a.a.17-26) and His126 (a.a 117-131) in C46A mutant significantly increased deuterium exchange levels. These results indicate that surrounding regions of Cys106 in C46A mutant are dramatically exposed to the protein surface, which is consistent with above proteomic results that Cys 106 residue in C46A mutant is further oxidized to sulfonic acid.

Additionally, the region near Ala46 (a.a 37-49) in C46A mutant also had increased exposure, indicating that Cys46-Cys53 intra-disulfide bond were released and became more flexible. The peptide of $\alpha \mathrm{G}$ (a.a 164-170) in helix-kink-helix motif which is essential for protein stability [18] also showed 
the significantly higher exchange level in C46A mutant. Meanwhile, the peptide (a.a 132-144) in the opposite side of Cys106 was more shielded in the mutant. And, the peptide (a.a 152-163) in helix of Cterminus showed similar exchange level in both WT and mutant. On the other hand, as a result of HDXMS analysis of oxidized WT, there was no significant difference from native WT except that the peptide including Cys46 was shielded and the peptide including Cys106 was increased (Supplementary Fig. 4). In summary, the results of these dynamic structural analyzes indicate that $\mathrm{C} 46 \mathrm{~A}$ mutant, not forming the intra-disulfide bond, undergoes significant conformational changes.

\section{C46A mutant is more unstable than WT in vitro}

To investigate protein stability of C46A mutant, not able to form Cys46-Cys53 intra-disulfide bond, we examined protein stability of WT and C46A mutant employing biophysical assessments of denaturation induced by heat or chemical denaturants. We measured CD ellipticity of WT and C46A mutant $(0.25 \mathrm{mg} / \mathrm{mL})$ at $222 \mathrm{~nm}$ by increasing temperature $\left(20-90^{\circ} \mathrm{C}\right)$ at a rate of $1^{\circ} \mathrm{C} / \mathrm{min}$. As shown in Fig. 5A, mid-point of thermal transitions, $T_{\mathrm{m}}$, were $61.3^{\circ} \mathrm{C}$ for $\mathrm{WT}$ and $51.5^{\circ} \mathrm{C}$ for $\mathrm{C} 46 \mathrm{~A}$ mutant. A dramatic destabilization effect was observed in C46A mutant which led to $9.8^{\circ} \mathrm{C}$ decrease in $T_{\mathrm{m}}$. Thus, WT has more stable structure than C46A mutant. In addition, protein folding was examined using the chemical denaturant, GdnHCl. Protein unfolding was investigated by measuring ANS fluorescence after treatment of various concentrations of $\mathrm{GdnHCl}$ using the properties of accumulating ANS bound to unfolded hydrophobic region of protein [45]. ANS fluorescence intensity of WT was increased at 0.6 M GdnHCl concentration, while that of C46A mutant was rapidly increased at $0.3 \mathrm{M}$ (Fig. 5B). This indicates that $\mathrm{C} 46 \mathrm{~A}$ mutant is more readily denaturized than WT. These results imply that the conformational change in C46A mutant may expose more hydrophobic areas on its molecular surface. Additionally, C46S, a conserved mutant, was confirmed to be unstable like C46A (Supplementary Fig. 5A), and C53A mutant, which does not form an intra-disulfide bond, was not as unstable as C46A, but more unstable than WT (Supplementary Fig. 5B). These results indicate that structure of C46A mutant is distorted due to the lack of Cys46-Cys53 intra-disulfide bond. 


\section{Cysteine 46 and 53 form an intra-disulfide bond in mammalian cell}

In order to verify in vitro results occur in mammalian cells, we examined the presence of intradisulfide bond in HeLa cells. HeLa cells transfected with Flag-WT and Cys mutants were immunoprecipitated with Flag antibody. The enriched WT and mutant DJ-1s were shown as two bands by SDS-PAGE in non-reducing conditions, while one band in reducing condition (Fig. 6A). Additionally this result was confirmed by Western analysis using Flag antibodies (Fig. 6B). These results indicate the possibility of the presence of intra-disulfide bond inside cells. This was confirmed by identifying Cys46-Cys53 intra-disulfide bond in cellular WT DJ-1 employing tandem MS analysis combining with DBond algorithm (Fig. 6C). Also, the presence of other type of intra-disulfide bond were detected in cellular Cys mutants as well as in recombinant ones (Supplementary Table 4). Cys53Cys106 intra-disulfide bond in C46A mutant was also identified with low intensity by tandem MS spectra (Supplementary Fig. 6). C53A mutant also showed down-shifted band to different position, suggesting that C53A mutant is presumed to form Cys46-Cys106 intra-disulfide bond. However, cellular DJ-1 did not form oligomer in response to oxidative stress.

Oxidative modifications of cellular DJ-1s showed similar tendency with in vitro results with recombinant proteins, but the details were slightly different (Supplementary Fig. 7, Supplementary Table 5). Cys106s in C46A mutant were more readily oxidized to sulfonic acid than WT. Cys106s in C53A mutant were also more readily oxidized than WT to sulfinic acid, sulfonic acid and thiosulfonic acid including Cys to Ser oxidation. Cys106 in Cys mutants not forming intra-disulfide bond, is more oxidized to irreversible oxidation. The difference in detail from in vitro results is assumed to be due to cellular equilibrium and complexity of cellular environment including protein-protein interaction etc.

\section{Intra-disulfide bond formation is required for DJ-1 cellular function}

Since protein structure is closely related to function, we investigated cellular functions of DJ-1 and its mutants. We examined the function of DJ-1 as a ROS scavenging protein [9] in SN4741 cells, dopaminergic neuronal cell line, and DJ-1 KO SN4741 cells derived from the substantia nigra of 
transgenic DJ-1 null mouse embryos in order to exclude endogenous DJ-1 activity [46, 47]. Several studies have reported that DJ-1 KO cells have increased ROS production compared to WT in the muscle [48], hematopoietic stem cell [49] and dopaminergic cell in Drosophila [46]. To identify whether DJ-1 deficiency is associated with cellular ROS level in dopaminergic cells as in the previous studies, we measured fluorescence generated by ROS after loading the cells with CM- $\mathrm{H}_{2}$ DCFDA in WT and DJ-1 KO SN4741 cells. DJ-1 KO SN4741 cells showed increased cellular ROS levels (Fig. 7A). Next, we examined whether cellular ROS level increased by DJ-1 KO is lowered when DJ-1 is added back. Intracellular ROS levels were measured in DJ-1 KO SN4741 cells transfected with WT and three Cys mutants. Overexpression of WT and Cys mutants did not affect the intracellular ROS levels, however, when transfected cells were treated with $0.5 \mathrm{mM} \mathrm{H}_{2} \mathrm{O}_{2}$ for 20 min at $33^{\circ} \mathrm{C}$, overexpression of WT DJ-1, not Cys mutants, decreased intracellular ROS level (Fig. 7B). Thus, the results suggest that all three Cys mutants, unlike WT DJ-1, lost their ROS scavenging activity as antioxidant protein.

DJ-1 is known to protect neurons against damage though mediating cell proliferation by activating the extracellular signal-regulated kinase (ERK1/2) pathway [50]. To investigate whether SN4741 cells are also enabled for DJ-1 dependent ERK signaling, WT and DJ-1 KO SN4741 cells were treated with $0.5 \mathrm{mM} \mathrm{H}_{2} \mathrm{O}_{2}$ at $33^{\circ} \mathrm{C}$ for indicated times and phosphorylation levels of ERK were measured using Western analysis. ERK activation was reduced in DJ-1 KO cells than WT (Fig. 8A). Then, DJ-1 KO SN4741 cells transiently transfected with Flag empty vector and Flag-DJ-1 WT were treated with 0.5 $\mathrm{mM} \mathrm{H} \mathrm{H}_{2} \mathrm{O}_{2}$ at $33^{\circ} \mathrm{C}$ for various times. Overexpression of WT DJ-1 increased the phosphorylation level of ERK signaling, especially when $\mathrm{H}_{2} \mathrm{O}_{2}$ was treated for $20 \mathrm{~min}$, the maximum difference in ERK activation was observed (Fig. 8B). When DJ-1 KO SN4741 cells transfected with Flag, WT and three Cys mutants were treated with $0.5 \mathrm{mM} \mathrm{H}_{2} \mathrm{O}_{2}$ for 20 min, ERK activations are shown in Fig. 8C. Overexpression of WT increased ERK activation, but all three Cys mutants did not. The results also suggest that all three Cys residues are required to activate ERK signal transduction.

Since ERK signaling pathways in cell proliferation play a critical role in neuroprotection [51, 52], 
we examined cell proliferation in DJ-1 KO SN4741 cells transfected with Flag, WT and three Cys mutants employing a real-time cell analyzer, xCelligence, based on the conductivity of attached cells on the gold surface. There were no discernible differences in the proliferation of DJ-1 KO SN4741 cells transfected with WT and Cys mutants without oxidative stress (Fig. 9A). However, the apparent increase of proliferation in response to oxidative stress was detected in cells transfected with WT DJ-1, not three Cys mutants (Fig. 9B). These results demonstrate that all three Cys residues are necessary and Cys46Cys53 intra-disulfide bond formation is required to play the cellular function of DJ-1.

\section{Discussion}

Our results establish that Cys46 in DJ-1 is also reactive cysteine and is easily oxidized to form Cys46Cys53 intra-disulfide bonds, preventing active site Cys106 from being over-oxidized. Cys mutants, not able to form intra-disulfide bonds lose their antioxidant activity due to structural changes, which prevents them from functioning to promote cell proliferation. Thus, Cys46-Cys53 intra-disulfide bond in DJ-1 is believed to play an important role in structural integrity by maintaining the proper oxidative state of Cys106 and in antioxidant activity to protect cells from oxidative stress.

This is the first study focusing on the reactivity of Cys46 residues and the resulting Cys46-Cys53 intra-disulfide binding in the structure and function of DJ-1. Among three cysteine residues in DJ-1, studies on Cys 106 have been more advanced than the other cysteine residues, and several studies have reported that Cys106 in DJ-1 is the most reactive and readily oxidized [30,33]. Unlike Cys106, Cys46 and Cys53 are not modified but their mutants lose their function. This suggests that Cys46 and Cys53 play key roles in dimer formation via hydrophobic interaction of surface [33, 35]. However, both C46A and C53A mutants also can produce dimers via DSS crosslinker [35], which correlates with the results of size-exclusion chromatography in which all three Cys mutants were separated at same retention time (data not shown). The C46A mutant has the result of not being able to create a dimer in the cell [35], so the results of the dimer formation are still controversial. This suggests the possibility that inactivation 
of the C46A and C53A mutants may be due to disulfide bond formation, not dimer formation. Previous study has reported that DJ-1 is a redox-dependent chaperone preventing $\alpha$-synuclein aggregate formation [53]. They showed the chaperone ability of DJ-1 was decreased when assay was performed in a reduced environment using reducing agent, DTT. They interpreted redox regulation governs DJ-1 chaperone activity. However, this study indicates another possibility that intra-disulfide bond of DJ-1 is necessary for functioning as a chaperone. Therefore, this study suggests for the first time that malfunction of Cys mutants can be derived from disability to form intra-disulfide bond.

Redox sensitive Cys residues can be modified to numerous ways. However, Cys46, the reactive Cys residue in DJ-1, did not show various oxidative modifications. This indicates that Cys46 has a strong tendency to form intra-disulfide bond with adjacent Cys53 rather than oxidative modifications. The consequent structural stability obtained by intra-disulfide bond maintains the reactivity of Cys106, which can be a mechanism for regulating the activity of Cys106. There is a similar example where three Cys residues work cooperatively. A tumor metastasis suppressor protein, Nm23-H1/NDPK-A, is a redox sensitive protein with three cysteine residues [54]. The most reactive cysteine, a peroxidatic cysteine, Cys4 in Nm23-H1 also easily forms an intra-disulfide bond with adjacent resolving cysteine. Therefore, oxidative modifications were not observed in Cys4 residue as Cys46 of DJ-1 [24]. Cys4 forms intradisulfide bond with Cys145 in response to oxidative stress, thereby Cys109 residue is exposed to the surface and oxidized to sulfonic acid through a quaternary structural change, which lost the enzymatic activity of NDPK-A. Both cases show how stepwise oxidation regulates protein structure and activity. These findings broaden knowledge about stepwise molecular regulations of cysteine residues. Therefore, this study provides a new perspective for further studying and designing new experiments to reveal regulation mechanisms of DJ-1 in reactive cysteines cooperatively.

We have shown a pattern of oxidative modifications at cysteine residues of WT and mutant DJ-1s (Fig. 3). The analysis with the combined result provides conclusive behavior among cysteines. All three cysteines collaborate together for proper molecular functions. Cys46 and Cys53 form intra-disulfide 
bonds, but the modification of the two is different. Compared to Cys46, Cys53 has been oxidized in various forms. As already known, Cys46 is structurally embedded in the protein. So, despite being reactive by itself, no modification is observed because it forms disulfide with the nearby Cys53. On the other hand, since Cys53 is present on the protein surface, it is easy to react with a solvent, so it is thought that it is oxidized in various forms as well as intra-disulfide bonds. In addition, intra-disulfide bond between Cys46 and Cys53 is also crucial to keep the oxidation state of Cys106 not into sulfonylation but sulfinylation. Previous studies also suggest that the degree of oxidation of Cys106 is dependent on the presence or absence of Cys 46 and Cys53 $[55,56]$. The results suggest that disulfide formation modulates redox state of the other cysteine residue.

Since intra-disulfide bond formation is a typical modification that alters the structure of proteins, structural dynamics were examined by HDX-MS. Previous studies have reported that Cys 106 is located in a putatively nucleophile elbow region, the sharp turn between a $\beta$-sheet and an $\alpha$-helix, in solvent accessible branched $[12,37,57]$. Although Cys106 is known as the most reactive Cys residue and readily oxidized, it is structurally buried and could be controlled precisely. The crystal structure of native DJ-1 (Supplementary Fig. 8) implies the spatial relation of three cysteine residues and explains the possible formation of Cys53-Cys106 intra-disulfide bond in C46A mutant. In the crystal structure, Cys 106 is regulated by Glu18 residing on $\alpha$ A helix which interacts with a flexible domain composed of four $\beta$-strands ( $\beta 2-5)$. Intriguingly, two cysteine residues, Cys46 and Cys53, are located on a $\beta$-sheet composed of $\beta 2$ and $\beta 4$. However, in the case of C46A mutant, Cys53-Cys106 intra-disulfide bond was formed as proven by HDX-MS experiment. It is plausible due to the presence of two long hinge loops of flexible domain. Since there is no intra-disulfide bond in Cys46-Cys53, the flexible domain can be inverted. HDX-MS strongly supports this situation as shown in the increased deuterium exchange level in this domain. In addition, deuterium exchange levels of peptide containing Cys106 and peptides containing Glu18 and His126 were also increased. The rapid deuterium exchange at the catalytic site confirms the movement of adjacent helix $\alpha \mathrm{A}$ and thus indicates the occurrence of large conformational changes in C46A mutant. 
In summary, the results suggest that intra-disulfide bond and cysteine regulation of DJ-1 are important for its structure and function and broaden the understanding of the complicated regulatory mechanisms of DJ-1 that operate under oxidative environments. To understand the regulation mechanism how to be modulated between cysteine residues of DJ-1 provides insight to understand neurodegenerative disease and find a novel therapy focusing on DJ-1.

\section{Data availability}

The structures presented in this paper have all been deposited in the Protein Data Bank (PDB) with the following codes: 4RKW

Raw data for DJ-1 PTM analysis and HDX analysis (Figure 1C, 2B, 3, 4, 6, Table 1, Supplementary Table 2-5) are available via ProteomeXchange with identifier PXD020690 [60]. Reviewer account details are as follows; Username: reviewer58222@ebi.ac.uk, Password: QXG0L9LO.

\section{Acknowledgements}

We are grateful to Jin Son (Ewha Womans University, Korea) for donating SN4741 and DJ-1(-/-) cell lines. Authors appreciate technical support of MS analysis performed by Mr. Kang W.

\section{Funding and additional information}

This work was supported by NRF grant (No. 2020R1F1A1055369) of National Research Foundation of Korea. I.K. Song was supported by Brain Korea 21 Plus (BK21 Plus) Project.

Conflict of Interest: The authors declare no conflicts of interest in regards to this manuscript.

Author contributions: IKS and KJL designed the study, IKS conducted most of the experiments and analyzed the results. MSK and DHS designed and performed biophysical assay, and JEF did orthogonal sequence analysis. IKS, KJL and DHS wrote the paper. 


\section{Figure legends}

Fig. 1. Cys46 is the most reactive residue in DJ-1. (A) Alignment of amino acid sequences in DJ-1. Cys46 residue and Cys106 residue are well-conserved. (B) Recombinant WT and Cys mutant DJ-1 proteins were incubated with indicated concentrations of $\mathrm{H}_{2} \mathrm{O}_{2}$ at $37^{\circ} \mathrm{C}$ for $1 \mathrm{~h}$ followed by treatment with $1 \mathrm{mM}$ NPSB-B at RT for $2 \mathrm{~h}$. Proteins were separated on reducing SDS-PAGE and detected by streptavidin-HRP. Coomassie staining gel showing amount of gel loaded proteins. NPSB-B labeling were quantified and normalized with loading control. Data are presented as mean \pm S.D. of triplicated experiments (Two tailed t-test; * $P<0.05$ ). (C) Tandem mass spectrum of NPSB-1 labeled at Cys46 residue in WT DJ-1. WT protein was tested in same way as NPSB-B, separated by SDS-PAGE, and stained with Coomassie blue, then labeled bands were cut out of gel and analyzed by MS, and PTM analysis was performed.

Fig. 2. DJ-1 has a Cys46-Cys53 disulfide bond in recombinant proteins. (A) Purified WT and Cys mutants DJ-1 proteins were incubated with $0,0.01,0.1$ or $1 \mathrm{mM} \mathrm{H}_{2} \mathrm{O}_{2}$ at $37^{\circ} \mathrm{C}$ for $1 \mathrm{~h}$. Proteins were separated by SDS-PAGE under non-reducing $(-\beta-\mathrm{ME})$ and reducing $(+\beta-\mathrm{ME})$ conditions, and detected by Coomassie blue-staining. (B) Tandem mass spectrum of Cys46-Cys53 disulfide bond peptide of WT DJ-1 band without $\mathrm{H}_{2} \mathrm{O}_{2}$ treatment in Fig. 2A. Coomassie-stained gel bands were cut out of gel and analyzed by MS and Dbond algorithm.

Fig. 3. Each cysteine influences the oxidation state of other cysteines with different modifications. (A-D) Oxidative modifications of WT and Cys mutants DJ-1 protein bands in Fig 2A without $\mathrm{H}_{2} \mathrm{O}_{2}$ treatment under reducing condition were examined by MS/MS analysis employing SEMSA strategy and Mascot search algorithm. MS/MS spectra of modified peptides are presented in Supplementary Fig. 3. Numbers of oxidized peptides in (B) Cys106, (C) Cys46 and (D) Cys53 residue in WT and Cys mutant DJ-1s were presented with mass coverage. Various oxidative modifications such as sulfinic acid, sulfonic acid and conversion of Cys to thiosulfonic acid $(\Delta \mathrm{m}=+64 \mathrm{Da})$ were found.

Fig. 4. Identification of structural changes in WT and C46A mutant DJ-1 employing HDX-MS. 
(A-C) Recombinant WT and C46A mutant DJ-1 proteins were incubated with $\mathrm{D}_{2} \mathrm{O}$ exchange buffer at $25^{\circ} \mathrm{C}$ for various times upto $30 \mathrm{~min}$ and analyzed using nanoAcquity ${ }^{\mathrm{TM}} / \mathrm{ESI} / \mathrm{MS}$. (A) Time course of HDX incorporation for representative peptides that showed differences in HDX. (B) Deuterium exchange rate (\%) of each peptide in WT and C46A mutant was presented depending on $\mathrm{D}_{2} \mathrm{O}$ incubation time. Significant differences between WT and C46A mutant were marked by colored arrows and no discernible changes by gray arrow. Corresponding deuterium exchange levels of each peptide in percent are given on the right. (C) Average deuterium exchange difference of C46A mutant compared to the WT in DJ-1 monomer structure (PBD ID code 4RKW).

Fig. 5. Protein stability and folding of DJ-1 proteins in response to denaturants. (A) Thermal unfolding profile of DJ-1 WT and C46A mutant by measuring CD ellipticity at $222 \mathrm{~nm}$. (B) Hydrophobic exposure during GdnHCl-induced unfolding was monitored by ANS fluorescence intensity at $470 \mathrm{~nm}$. WT and C46A mutant were incubated for $16 \mathrm{~h}$ with various concentrations of GdnHCl. Samples were prepared by mixing the protein with ANS stock solution to final molar ration of $75: 1$ (ANS : protein) and equilibrating in the dark for $30 \mathrm{~min}$ at RT. Fluorescent emission intensity at $470 \mathrm{~nm}$ was measured using an excitation wavelength $380 \mathrm{~nm}$. Data for each proteins were fitted with a Boltzmann curve using Origin 8.5.

Fig. 6. DJ-1 has Cys46-Cys53 disulfide bond in mammalian cell. (A, B) HeLa cells transfected with Flag-DJ-1 WT and Cys mutants were treated with 0 or $0.5 \mathrm{mM} \mathrm{H}_{2} \mathrm{O}_{2}$ in $37^{\circ} \mathrm{C}$ for $1 \mathrm{~h}$. The cell lysate were subjected to immunoprecipitation (IP) with anti-Flag antibody. Immune complexes were separated by SDS-PAGE under non-reducing ( $-\beta-\mathrm{ME})$ or reducing $(+\beta-\mathrm{ME})$ conditions and detected by $(\mathrm{A})$ silver staining and (B) Western analysis using anti-Flag antibody. (C) Tandem mass spectrum of Cys46-Cys53 disulfide bond peptide obtained from WT DJ-1 without $\mathrm{H}_{2} \mathrm{O}_{2}$ treatment under non-reducing condition in Fig. 6A.

Fig. 7. All three cysteine residues in DJ-1 are required for its role in antioxidant activity in neuronal cells. (A) Intracellular ROS level of WT and DJ-1 KO SN4741 cells were determined by 
FACS using $\mathrm{H}_{2}$ DCF-DA. Equal numbers of cells were treated with $2 \mu \mathrm{M}$ for 15 min at $33^{\circ} \mathrm{C}$ and immediately, the fluorescence intensity was measured. Relative ROS level is presented by Geomean value. (B) DJ-1 KO SN4741 cells transfected with Flag-DJ-1 WT and Cys mutants were treated with 0 or $0.5 \mathrm{mM} \mathrm{H}_{2} \mathrm{O}_{2}$ for $20 \mathrm{~min}$ at $33^{\circ} \mathrm{C}$ and then with $\mathrm{H}_{2} \mathrm{DCF}-\mathrm{DA}(2 \mu \mathrm{M})$ for $15 \mathrm{~min}$ in $33^{\circ} \mathrm{C}$, fluorescence intensity was measured. Data are presented as mean \pm S.D. of triplicate experiments (Two tailed t-test; $* * P<0.01, * * * P<0.001)$.

Fig. 8. All cysteine residues in DJ-1 are required for its role in ERK activation in neuronal cells. (A) WT and DJ-1 KO SN4741 cells were treated with $\mathrm{H}_{2} \mathrm{O}_{2}(0.5 \mathrm{mM})$ at $33^{\circ} \mathrm{C}$ for various times $(0,15$, 30 and $45 \mathrm{~min}$ ), then cells were lysed and ERK activations were detected by Western analysis using anti-phospho-ERK(T202/Y204) antibodies. (B) DJ-1 KO SN4741 cells transiently transfected with Flag or Flag DJ-1 WT were treated with $\mathrm{H}_{2} \mathrm{O}_{2}(0.5 \mathrm{mM})$ at $33^{\circ} \mathrm{C}$ for various times $(0,10,20,30$ and 40 min), then cells were lysed and ERK activations were detected by Western analysis using anti-phosphoERK antibodies. Quantitative analysis was done with multi-gauge software. (C) DJ-1 KO SN4741 cells transiently transfected with WT and Cys mutant Flag-DJ-1s were treated with $\mathrm{H}_{2} \mathrm{O}_{2}(0.5 \mathrm{mM})$ at $33^{\circ} \mathrm{C}$ for $20 \mathrm{~min}$ and then ERK activations were detected. Data are presented as mean \pm S.D. of triplicate experiments (Two tailed t-test; $* P<0.05, * * P<0.01$ and $* * * P<0.001$ ).

Fig. 9. All cysteine residues of DJ-1 are essential for cell proliferation in response to oxidative stress. (A, B) SN4741 DJ-1 KO cells transiently transfected with Flag empty vector, Flag-DJ-1 and Flag-DJ-1 Cys mutants were treated with (A) 0 or (B) $0.5 \mathrm{mM}$ of $\mathrm{H}_{2} \mathrm{O}_{2}$ at $33^{\circ} \mathrm{C}$ for $2 \mathrm{~h}$. Cells were then plated in $96-w e l l$ plate, incubated at $33^{\circ} \mathrm{C}$ for 3 days. Cell growth was monitored under real-time cell analyzer, xCELLigence. Data were presented as the means \pm S.D. of triplicated experiments.

\section{References}


and Olanow, C. W. (2000) Pathophysiology of the basal ganglia in Parkinson's disease. Trends

Neurosci. 23, S8-19

2 Dawson, T. M. and Dawson, V. L. (2003) Molecular pathways of neurodegeneration in

Parkinson's disease. Science. 302, 819-822

3 Mastroberardino, P. G., Hoffman, E. K., Horowitz, M. P., Betarbet, R., Taylor, G., Cheng, D., Na,

H. M., Gutekunst, C. A., Gearing, M., Trojanowski, J. Q., Anderson, M., Chu, C. T., Peng, J. and Greenamyre, J. T. (2009) A novel transferrin/TfR2-mediated mitochondrial iron transport system is disrupted in Parkinson's disease. Neurobiol Dis. 34, 417-431

4 Bonifati, V., Rizzu, P., van Baren, M. J., Schaap, O., Breedveld, G. J., Krieger, E., Dekker, M. C., Squitieri, F., Ibanez, P., Joosse, M., van Dongen, J. W., Vanacore, N., van Swieten, J. C., Brice, A., Meco, G., van Duijn, C. M., Oostra, B. A. and Heutink, P. (2003) Mutations in the DJ-1 gene associated with autosomal recessive early-onset parkinsonism. Science. 299, 256-259

5 Bjorkblom, B., Maple-Grodem, J., Puno, M. R., Odell, M., Larsen, J. P. and Moller, S. G. (2014) Reactive oxygen species-mediated DJ-1 monomerization modulates intracellular trafficking involving karyopherin beta2. Mol Cell Biol. 34, 3024-3040 Meulener, M., Whitworth, A. J., Armstrong-Gold, C. E., Rizzu, P., Heutink, P., Wes, P. D., Pallanck, L. J. and Bonini, N. M. (2005) Drosophila DJ-1 mutants are selectively sensitive to environmental toxins associated with Parkinson's disease. Curr Biol. 15, 1572-1577 
analysis of DJ-1 in Drosophila implicates functional inactivation by oxidative damage and aging.

Proc Natl Acad Sci U S A. 103, 12517-12522

8 Park, J., Kim, S. Y., Cha, G. H., Lee, S. B., Kim, S. and Chung, J. (2005) Drosophila DJ-1 mutants show oxidative stress-sensitive locomotive dysfunction. Gene. 361, 133-139

9 Taira, T., Saito, Y., Niki, T., Iguchi-Ariga, S. M., Takahashi, K. and Ariga, H. (2004) DJ-1 has a role in antioxidative stress to prevent cell death. EMBO Rep. 5, 213-218

10 Biosa, A., Sandrelli, F., Beltramini, M., Greggio, E., Bubacco, L. and Bisaglia, M. (2017) Recent findings on the physiological function of DJ-1: Beyond Parkinson's disease. Neurobiol Dis. 108, 6572

11 Miller, D. W., Ahmad, R., Hague, S., Baptista, M. J., Canet-Aviles, R., McLendon, C., Carter, D. M., Zhu, P. P., Stadler, J., Chandran, J., Klinefelter, G. R., Blackstone, C. and Cookson, M. R. (2003) L166P mutant DJ-1, causative for recessive Parkinson's disease, is degraded through the ubiquitinproteasome system. J Biol Chem. 278, 36588-36595

12 Wilson, M. A., Collins, J. L., Hod, Y., Ringe, D. and Petsko, G. A. (2003) The 1.1-A resolution crystal structure of DJ-1, the protein mutated in autosomal recessive early onset Parkinson's disease. Proc Natl Acad Sci U S A. 100, 9256-9261

13 Gorner, K., Holtorf, E., Odoy, S., Nuscher, B., Yamamoto, A., Regula, J. T., Beyer, K., Haass, C. and Kahle, P. J. (2004) Differential effects of Parkinson's disease-associated mutations on stability and folding of DJ-1. J Biol Chem. 279, 6943-6951 
Therapeutic Perspectives. J Clin Med. 8

15

Saito, Y. (2014) Oxidized DJ-1 as a possible biomarker of Parkinson's disease. J Clin Biochem

Nutr. 54, 138-144

of the type I glutamine amidotransferase superfamily. Proteins. 42, 230-236

17 Maita, C., Maita, H., Iguchi-Ariga, S. M. and Ariga, H. (2013) Monomer DJ-1 and its Nterminal sequence are necessary for mitochondrial localization of DJ-1 mutants. PLoS One. 8, e54087

and Kahle, P. J. (2007) Structural determinants of the C-terminal helix-kink-helix motif essential for protein stability and survival promoting activity of DJ-1. J Biol Chem. 282, 13680-13691

19 Witt, A. C., Lakshminarasimhan, M., Remington, B. C., Hasim, S., Pozharski, E. and Wilson, M. A. (2008) Cysteine pKa depression by a protonated glutamic acid in human DJ-1. Biochemistry. 47, 7430-7440

resolution crystal structure of YDR533Cp from Saccharomyces cerevisiae: a member of the DJ1/ThiJ/Pfpl superfamily. Proc Natl Acad Sci U S A. 101, 1531-1536

21 Girotto, S., Cendron, L., Bisaglia, M., Tessari, I., Mammi, S., Zanotti, G. and Bubacco, L. (2014)

DJ-1 is a copper chaperone acting on SOD1 activation. J Biol Chem. 289, 10887-10899 
and structural characterization of the specific binding of $\mathrm{Zn}(\mathrm{II})$ to human protein DJ-1. Biochemistry.

53, 2218-2220

for determining protein structural changes in drug discovery. Arch Pharm Res. 38, 1737-1745

24 Kim, M. S., Jeong, J., Jeong, J., Shin, D. H. and Lee, K. J. (2013) Structure of Nm23-H1 under oxidative conditions. Acta Crystallogr D Biol Crystallogr. 69, 669-680

25 Song, I. K., Lee, J. J., Cho, J. H., Jeong, J., Shin, D. H. and Lee, K. J. (2016) Degradation of Redox-Sensitive Proteins including Peroxiredoxins and DJ-1 is Promoted by Oxidation-induced Conformational Changes and Ubiquitination. Sci Rep. 6, 34432

26 Lee, J. J., Yang, S. Y., Park, J., Ferrell, J. E., Jr., Shin, D. H. and Lee, K. J. (2017) Calcium Ion Induced Structural Changes Promote Dimerization of Secretagogin, Which Is Required for Its Insulin Secretory Function. Sci Rep. 7, 6976

27 Song, E. J., Kim, Y. S., Chung, J. Y., Kim, E., Chae, S. K. and Lee, K. J. (2000) Oxidative modification of nucleoside diphosphate kinase and its identification by matrix-assisted laser desorption/ionization time-of-flight mass spectrometry. Biochemistry. 39, 10090-10097

28 Nelson, J. W. and Creighton, T. E. (1994) Reactivity and ionization of the active site cysteine residues of DsbA, a protein required for disulfide bond formation in vivo. Biochemistry. 33, 5974- 
multimerization of Ask1 and its reduction by thioredoxin-1 regulate $\mathrm{H}(2) \mathrm{O}(2)$-induced c-Jun $\mathrm{NH}(2)$ -

terminal kinase activation and apoptosis. Mol Biol Cell. 18, 3903-3913

30 Canet-Aviles, R. M., Wilson, M. A., Miller, D. W., Ahmad, R., McLendon, C., Bandyopadhyay,

S., Baptista, M. J., Ringe, D., Petsko, G. A. and Cookson, M. R. (2004) The Parkinson's disease protein

DJ-1 is neuroprotective due to cysteine-sulfinic acid-driven mitochondrial localization. Proc Natl

Acad Sci U S A. 101, 9103-9108

31

Kragelund, B. B., Poulsen, K., Andersen, K. V., Baldursson, T., Kroll, J. B., Neergard, T. B., Jepsen,

J., Roepstorff, P., Kristiansen, K., Poulsen, F. M. and Knudsen, J. (1999) Conserved residues and their role in the structure, function, and stability of acyl-coenzyme A binding protein. Biochemistry. $\mathbf{3 8}$,

2386-2394

32

Mitsumoto, A., Nakagawa, Y., Takeuchi, A., Okawa, K., Iwamatsu, A. and Takanezawa, Y. (2001)

Oxidized forms of peroxiredoxins and DJ-1 on two-dimensional gels increased in response to sublethal levels of paraquat. Free Radic Res. 35, 301-310

sensitive cysteine residue to hydrogen peroxide-mediated oxidation in vivo in human umbilical vein endothelial cells. Biochem Biophys Res Commun. 317, 722-728 
S-nitrosylation and dimerization of DJ-1. Biochem Biophys Res Commun. 339, 667-672

Mammi, S. (2012) Dopamine-derived quinones affect the structure of the redox sensor DJ-1 through modifications at Cys-106 and Cys-53. J Biol Chem. 287, 18738-18749

37 Honbou, K., Suzuki, N. N., Horiuchi, M., Niki, T., Taira, T., Ariga, H. and Inagaki, F. (2003) The crystal structure of DJ-1, a protein related to male fertility and Parkinson's disease. J Biol Chem. 278, $31380-31384$

for monitoring protein redox sensitivity. ACS Chem Biol. 9, 2883-2894

R., Messier, E., Reisdorph, N., Powell, R. L., Tang, H. Y., Mason, R. J., Criner, G. J. and Kosmider, B.

(2019) The effect of cysteine oxidation on DJ-1 cytoprotective function in human alveolar type II cells. Cell Death Dis. 10, 638

for the identification of intact disulfide linkages based on fragmentation characteristics in tandem mass spectra. J Proteome Res. 9, 626-635 
Proteomics. 10, M110 000513

42

Jeong, J., Kim, Y., Kyung Seong, J. and Lee, K. J. (2012) Comprehensive identification of novel

post-translational modifications in cellular peroxiredoxin 6. Proteomics. 12, 1452-1462

43

Choi, M. S., Nakamura, T., Cho, S. J., Han, X., Holland, E. A., Qu, J., Petsko, G. A., Yates, J. R.,

3rd, Liddington, R. C. and Lipton, S. A. (2014) Transnitrosylation from DJ-1 to PTEN attenuates

neuronal cell death in parkinson's disease models. J Neurosci. 34, 15123-15131

44 Pettersen, E. F., Goddard, T. D., Huang, C. C., Couch, G. S., Greenblatt, D. M., Meng, E. C. and

Ferrin, T. E. (2004) UCSF Chimera--a visualization system for exploratory research and analysis. J

Comput Chem. 25, 1605-1612

45 Povarova, O. I., Kuznetsova, I. M. and Turoverov, K. K. (2010) Differences in the pathways of proteins unfolding induced by urea and guanidine hydrochloride: molten globule state and aggregates. PLoS One. 5, e15035

46 Yang, J., Kim, M. J., Yoon, W., Kim, E. Y., Kim, H., Lee, Y., Min, B., Kang, K. S., Son, J. H., Park, H. T., Chung, J. and Koh, H. (2017) Isocitrate protects DJ-1 null dopaminergic cells from oxidative stress through NADP+-dependent isocitrate dehydrogenase (IDH). PLoS Genet. 13, e1006975

47 Shim, J. H., Yoon, S. H., Kim, K. H., Han, J. Y., Ha, J. Y., Hyun, D. H., Paek, S. H., Kang, U. J., Zhuang, X. and Son, J. H. (2011) The antioxidant Trolox helps recovery from the familial Parkinson's disease-specific mitochondrial deficits caused by PINK1- and DJ-1-deficiency in dopaminergic neuronal cells. Mitochondrion. 11, 707-715 
Patel, P., Kim, R. H., Bombardier, E., Quadrilatero, J., Tupling, A. R., Mak, T. W., Winer, D. A. and Woo, M. (2015) DJ-1 links muscle ROS production with metabolic reprogramming and systemic energy homeostasis in mice. Nat Commun. 6, 7415

49 Tai-Nagara, I., Matsuoka, S., Ariga, H. and Suda, T. (2014) Mortalin and DJ-1 coordinately regulate hematopoietic stem cell function through the control of oxidative stress. Blood. 123, 41-50 50 Oh, S. E. and Mouradian, M. M. (2018) Cytoprotective mechanisms of DJ-1 against oxidative stress through modulating ERK1/2 and ASK1 signal transduction. Redox Biol. 14, 211-217

51 Zhang, W. and Liu, H. T. (2002) MAPK signal pathways in the regulation of cell proliferation in mammalian cells. Cell Res. 12, 9-18

52 Karmarkar, S. W., Bottum, K. M., Krager, S. L. and Tischkau, S. A. (2011) ERK/MAPK is essential for endogenous neuroprotection in SCN2.2 cells. PLoS One. 6, e23493

53 Shendelman, S., Jonason, A., Martinat, C., Leete, T. and Abeliovich, A. (2004) DJ-1 is a redoxdependent molecular chaperone that inhibits alpha-synuclein aggregate formation. PLoS Biol. 2, e362

54 Lee, E., Jeong, J., Kim, S. E., Song, E. J., Kang, S. W. and Lee, K. J. (2009) Multiple functions of Nm23-H1 are regulated by oxido-reduction system. PLoS One. 4, e7949

55 Fernandez-Caggiano, M., Schroder, E., Cho, H. J., Burgoyne, J., Barallobre-Barreiro, J., Mayr, M. and Eaton, P. (2016) Oxidant-induced Interprotein Disulfide Formation in Cardiac Protein DJ-1 
Occurs via an Interaction with Peroxiredoxin 2. J Biol Chem. 291, 10399-10410

56 Waak, J., Weber, S. S., Gorner, K., Schall, C., Ichijo, H., Stehle, T. and Kahle, P. J. (2009)

Oxidizable residues mediating protein stability and cytoprotective interaction of DJ-1 with apoptosis signal-regulating kinase 1. J Biol Chem. 284, 14245-14257

57 Nair, D. N., Prasad, R., Singhal, N., Bhattacharjee, M., Sudhakar, R., Singh, P., Thanumalayan,

S., Kiran, U., Sharma, Y. and Sijwali, P. S. (2018) A conserved human DJ1-subfamily motif (DJSM) is critical for anti-oxidative and deglycase activities of Plasmodium falciparum DJ1. Mol Biochem Parasitol. 222, 70-80

58 Seo, J., Jeong, J., Kim, Y. M., Hwang, N., Paek, E. and Lee, K. J. (2008) Strategy for comprehensive identification of post-translational modifications in cellular proteins, including low abundant modifications: application to glyceraldehyde-3-phosphate dehydrogenase. J Proteome Res. 7, 587-602

(2006) MODi: a powerful and convenient web server for identifying multiple post-translational peptide modifications from tandem mass spectra. Nucleic Acids Res. 34, W258-263 
bioRxiv preprint doi: $\mathrm{https}$ //doi.org/10.1101/2021.01.25.428026; this version posted January 26, 2021. The copyright holder for this preprint (which was not certified by peer review) is the author/funder, who has granted bioRxiv a license to display the preprint in perpetuity. It is made available under aCC-BY 4.0 International license.

Nucleic Acids Res. 48, D1145-D1152 
Table 1. List of identified intra-disulfide bonds in WT and mutant DJ-1 recombinant protein bands under the non-reducing condition in Fig. 2A. Each protein band was digested with trypsin and analyzed with MS combining with DBond algorithm. MS/MS spectra are presented in Fig. 2B and Supplementary Fig. 2.

\begin{tabular}{|c|c|c|c|c|c|c|c|}
\hline & $\begin{array}{l}\mathrm{H}_{2} \mathrm{O}_{2} \\
(\mathrm{mM})\end{array}$ & $\begin{array}{c}\text { Disulfide } \\
\text { bond }\end{array}$ & $\begin{array}{c}\text { Mass }(\mathrm{m} / \mathrm{z}) \\
\text { Experimental } \\
\text { (Charge state) }\end{array}$ & $\begin{array}{c}\text { Mass } \\
\text { Theoretical }\end{array}$ & $\Delta \mathrm{m}(\mathrm{Da})$ & $\begin{array}{l}\text { Dbond } \\
\text { Score }\end{array}$ & Sequence \\
\hline \multirow{4}{*}{ WT } & 0 & & $601.7895(4+)$ & 2403.141 & -0.0121 & 58.6 & DPVQC*SR-DVVIC*PDASLEDAKK \\
\hline & 0.01 & Cys46- & $800.9005(4+)$ & 3199.6216 & -0.0487 & 266.3 & VTVAGLAGKDPVQC*SR-DVVIC*PDASLEDAKK \\
\hline & 0.1 & Cys53 & $800.9019(4+)$ & 3199.6216 & -0.0431 & 390.4 & VTVAGLAGKDPVQC*SR-DVVIC*PDASLEDAKK \\
\hline & 1 & & $800.902(4+)$ & 3199.6216 & -0.0427 & 313.7 & VTVAGLAGKDPVQC*SR-DVVIC*PDASLEDAKK \\
\hline \multirow{4}{*}{$\mathrm{C} 46 \mathrm{~A}$} & 0 & & & & & & N.D. \\
\hline & 0.01 & Cys53- & & & & & N.D. \\
\hline & 0.1 & Cys 106 & & & & & N.D. \\
\hline & 1 & & & & & & N.D. \\
\hline \multirow{4}{*}{$\mathrm{C} 53 \mathrm{~A}$} & 0 & & & & & & N.D. \\
\hline & 0.01 & Cys46- & $808.054(3+)$ & 2421.2144 & -0.0742 & 90.8 & DPVQC*SR-GLIAAIC*AGPTALLAHEIGFGSK \\
\hline & 0.1 & Cys 106 & & & & & N.D. \\
\hline & 1 & & & & & & N.D. \\
\hline \multirow{4}{*}{ C106A } & 0 & & $800.9137(4+)$ & 3199.6216 & 0.0041 & 310.8 & VTVAGLAGKDPVQC*SR-DVVIC*PDASLEDAKK \\
\hline & 0.01 & Cys46- & $803.344(2+)$ & 1604.7035 & -0.0301 & 140.1 & VTVAGLAGKDPVQC*SR-DVVIC*PDASLEDAKK \\
\hline & 0.1 & Cys53 & $768.8725(4+)$ & 3071.5267 & -0.0658 & 628.5 & VTVAGLAGKDPVQC*SR-DVVIC*PDASLEDAK \\
\hline & 1 & & $759.3374(3+)$ & 1604.7035 & -0.0406 & 193.8 & DPVQC*SR-DVVIC*PDASLEDAK \\
\hline
\end{tabular}

*N.D.: modified peptide were not detected 
bioRxiv preprint doi: https://doi.org/10.1101/2021.01.25.428026; this version posted January 26, 2021. The copyright holder for this preprint (which was not certified by peer review) is the author/funder, who has granted bioRxiv a license to display the preprint in perpetuity. It is made available under aCC-BY 4.0 International license. 
A

$\begin{array}{ll}\text { H.sapiens } & { }^{42} \text { DPVQCSRDVMICPDTSLED } \\ \text { M.musculus } & { }^{42} \text { DPVQCSRDVVI CPDASLED } \\ \text { M.domestica } & { }^{42} \text { DPVQCSRDVFI CPDESLED }^{60} \\ \text { D.rerio } & { }^{42} \text { EPVQCSREVMI CPDSSLED }^{60} \\ \text { D.melanogaster } & { }^{69} \text { EPVKCSRSVI VPDTSLEE }^{87} \\ \text { C.elegans } & { }^{43} \text { EPVKCARGAHIVPDVKLED } \\ \text { E.coli } & { }^{43} \text { LAITCSRGVKL LADAPLVE }^{61}\end{array}$

${ }^{101}$ IAAICAGPTALLAH ${ }^{126}$ ${ }^{101}$ IAAICAGPTALLAH ${ }^{126}$ ${ }^{101}$ IAAVC AGPTALLAH ${ }^{126}$ ${ }^{101}$ IAAICAGPTALLAH ${ }^{126}$ ${ }^{129}$ IAATCAAPTALAKH ${ }^{142}$ ${ }^{162}$ I GAIC AAPIA L LSH ${ }^{115}$ ${ }^{102}$ VAATCAAPATVL VP ${ }^{115}$
DJ-1

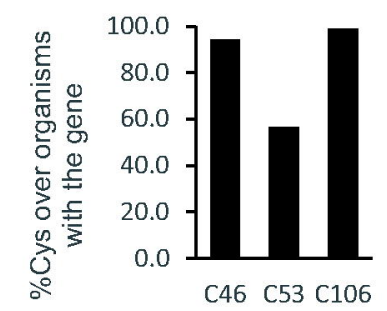

B

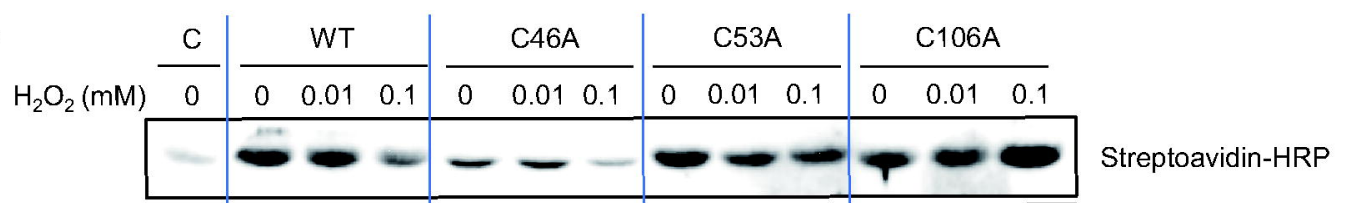

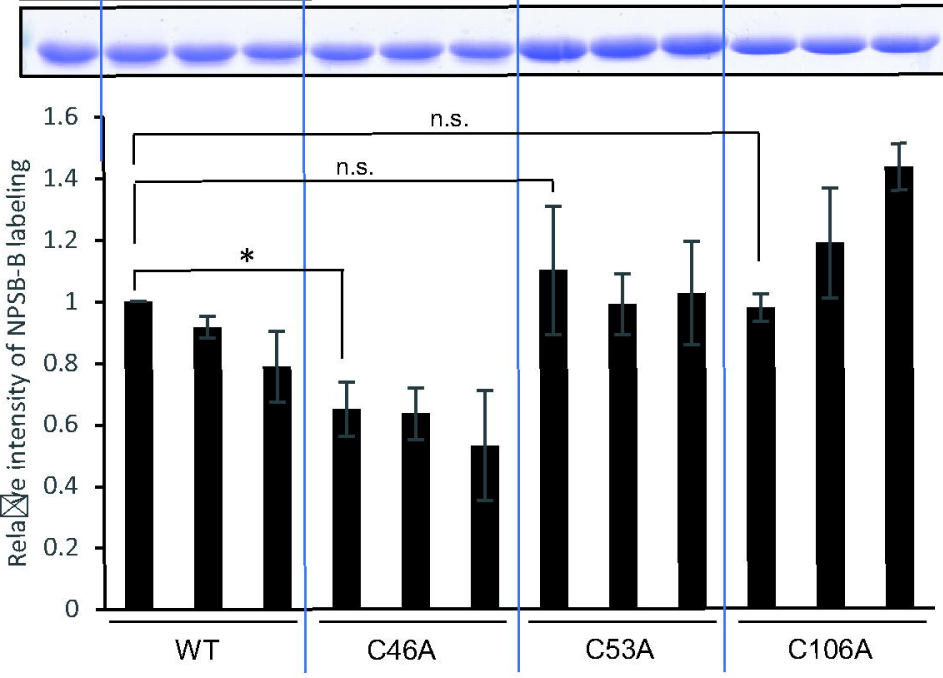
Loading control

C

DJ-1 Cys $46{ }^{33}$ VTVAGLAGKDPVQCSR ${ }^{48}$

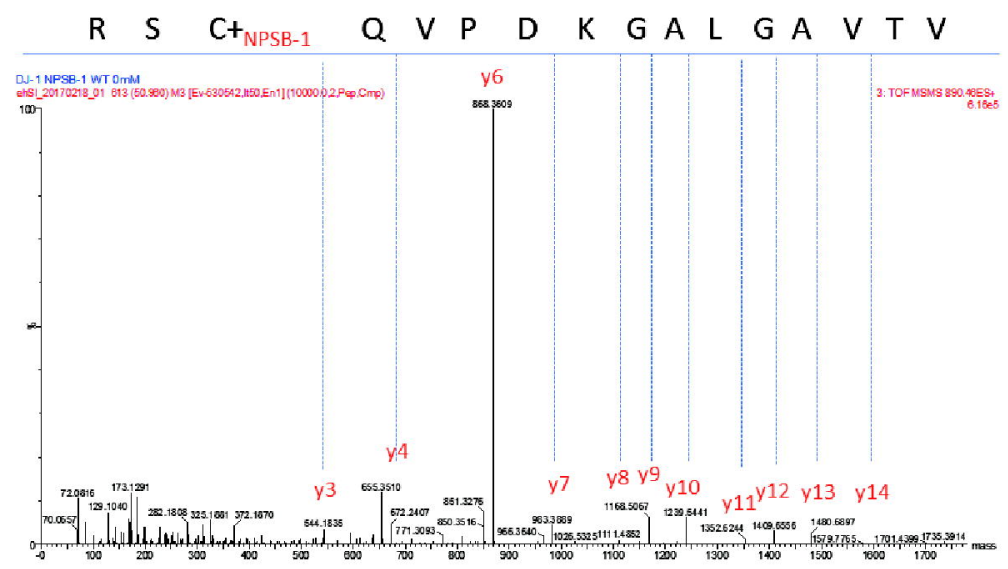

Figure 1. 

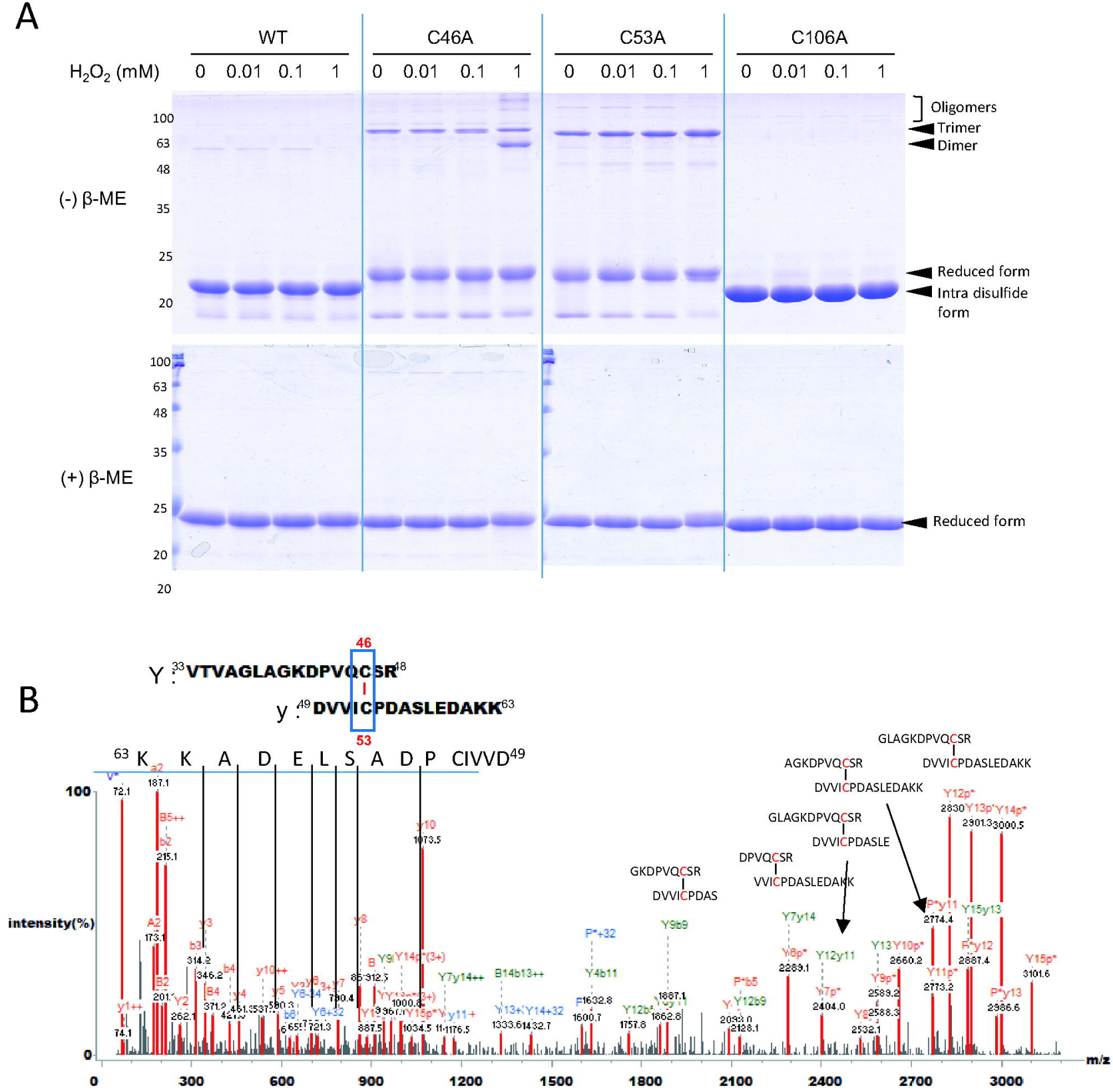

Figure 2. 


\begin{tabular}{|c|c|c|c|c|c|c|c|c|c|c|}
\hline Residue & Modification & Start-End & $\begin{array}{c}\text { Mass }(\mathrm{m} / \mathrm{z}) \\
\text { Experimental }\end{array}$ & $\begin{array}{c}\text { Mass } \\
\text { Theoretical }\end{array}$ & $\Delta \mathrm{m}(\mathrm{Da})$ & WT & $\mathrm{C} 46 \mathrm{~A}$ & $\mathrm{C} 53 \mathrm{~A}$ & $\mathrm{C} 106$ & Sequence \\
\hline \multirow[t]{4}{*}{$\mathrm{C} 106$} & Cys-SH & $99-122$ & $780.1085(3+)$ & 2337.2878 & 0.0158 & 34 & 20 & 21 & ND & KGLIAAICAGPTALLAHEIGFGSK \\
\hline & Cys- $\mathrm{SO}_{2} \mathrm{H}$ & $100-122$ & $748.0666(3+)$ & 2241.1827 & -0.0047 & 58 & 45 & 31 & ND & GLIAAICAGPTALLAHEIGFGSK \\
\hline & Cys- $\mathrm{SO}_{3} \mathrm{H}$ & $99-122$ & $796.0966(3+)$ & 2385.2726 & -0.0046 & 56 & 23 & 43 & ND & KGLIAAICAGPTALLAHEIGFGSK \\
\hline & Cys-SO ${ }_{2}-\mathrm{SH}$ & $100-122$ & $758.7240(2+)$ & 2273.1548 & -0.0046 & 45 & 34 & 35 & $\mathrm{ND}$ & GLIAAICAGPTALLAHEIGFGSK \\
\hline \multirow[t]{2}{*}{$\mathrm{C} 46$} & Cys-SH & $33-48$ & $800.9257(2+)$ & 1599.8403 & -0.0034 & 100 & ND & 93 & 97 & VTVAGLAGKDPVQCSR \\
\hline & Cys- $-\mathrm{SO}_{3} \mathrm{H}$ & $33-48$ & $824.9172(2+)$ & 1647.825 & -0.0052 & 40 & ND & ND & ND & \\
\hline \multirow[t]{4}{*}{$\mathrm{C} 53$} & Cys-SH (propionamide) & $49-63$ & $837.4424(2+)$ & 1672.8342 & -0.0039 & 62 & 64 & ND & 63 & DVVICPDASLEDAKK \\
\hline & Cys- $\mathrm{SO}_{2} \mathrm{H}$ & $49-63$ & $817.8992(2+)$ & 1633.7869 & -0.003 & 29 & 33 & ND & 32 & \\
\hline & Cys- $\mathrm{SO}_{3} \mathrm{H}$ & $49-63$ & $825.8963(2+)$ & 1649.7818 & -0.0038 & 62 & 53 & ND & 43 & \\
\hline & $\mathrm{Cys}-\mathrm{SO}_{2}-\mathrm{SH}$ & $49-63$ & $833.8846(2+)$ & 1665.759 & -0.0043 & 19 & 29 & ND & 30 & \\
\hline
\end{tabular}

\section{B}

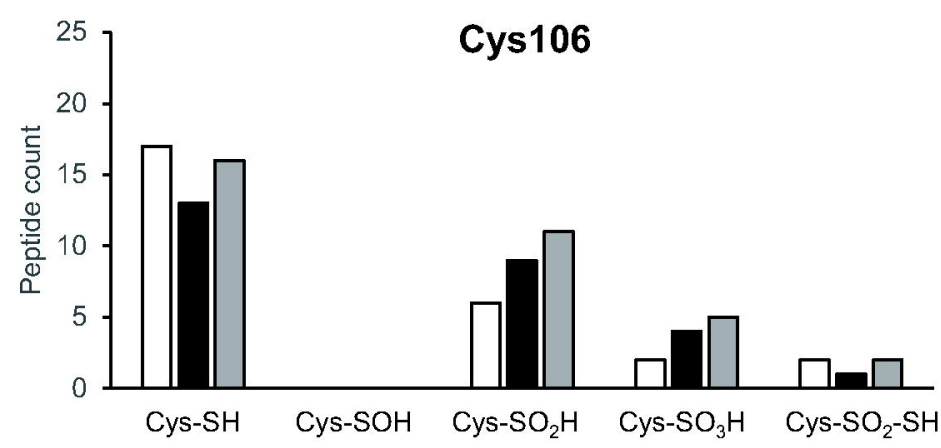

口WT (coverage : 91\%) —C46A (coverage : 90\%) पC53A (coverage : 81\%)

C

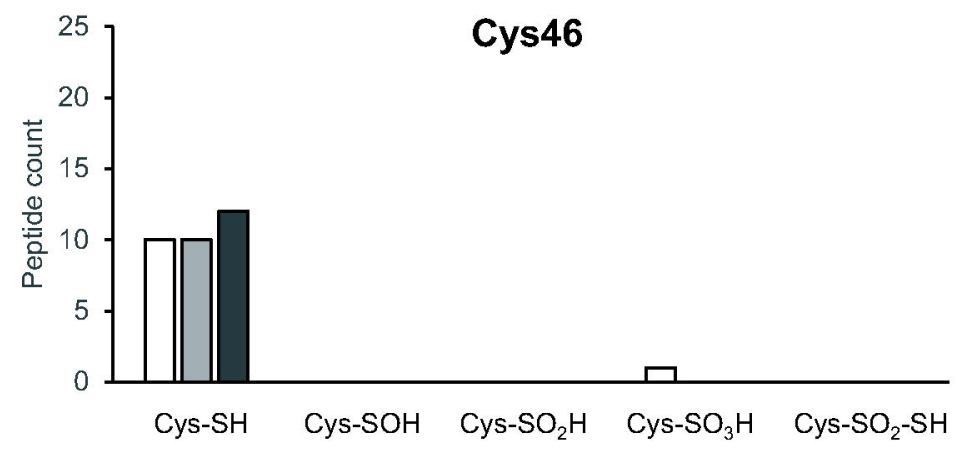

口WT (coverage : 91\%) पC53A (coverage : 81\%) पC106A (coverage : 88\%)

D

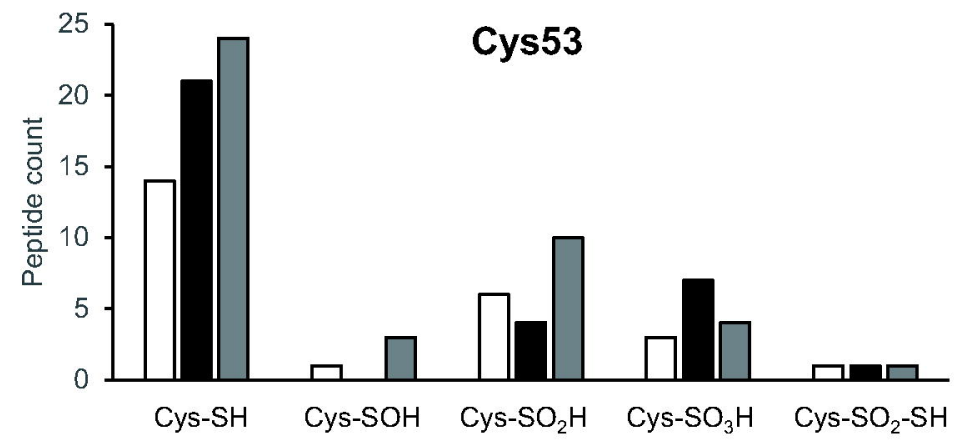

口WT (coverage : 91\%) DC46A (coverage : 90\%) पC106A (coverage : 88\%)

Figure 3. 


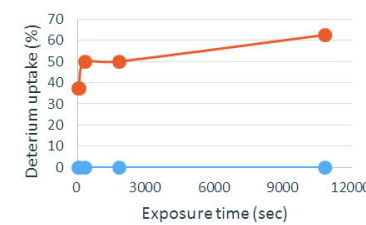

${ }^{132}$ KMMNGGHYTYSEN ${ }^{144}$

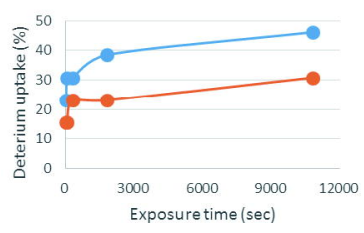

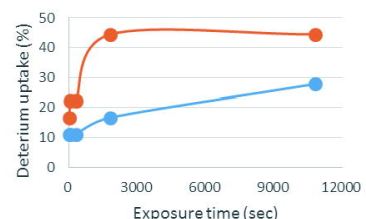

${ }^{164}$ FALAIVE ${ }^{170}$

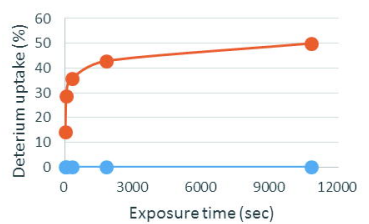

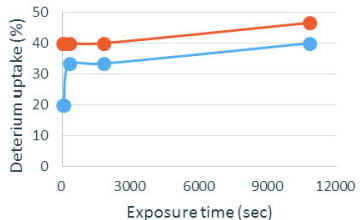

${ }^{152}$ ILTSRGPGTSFE ${ }^{163}$

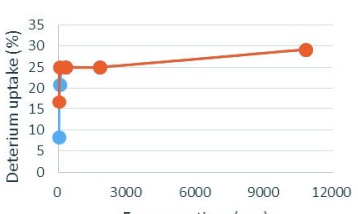

B

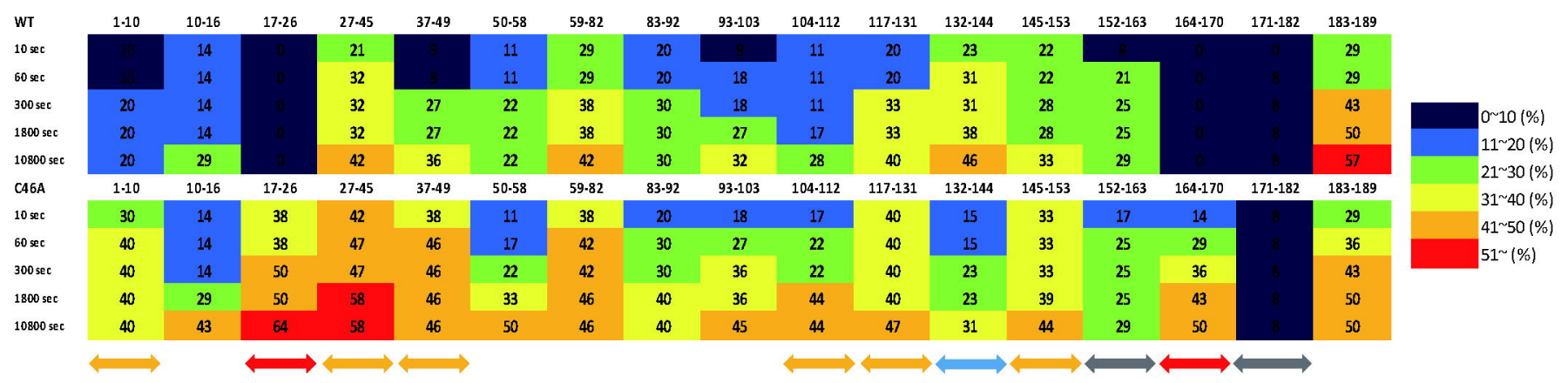

C
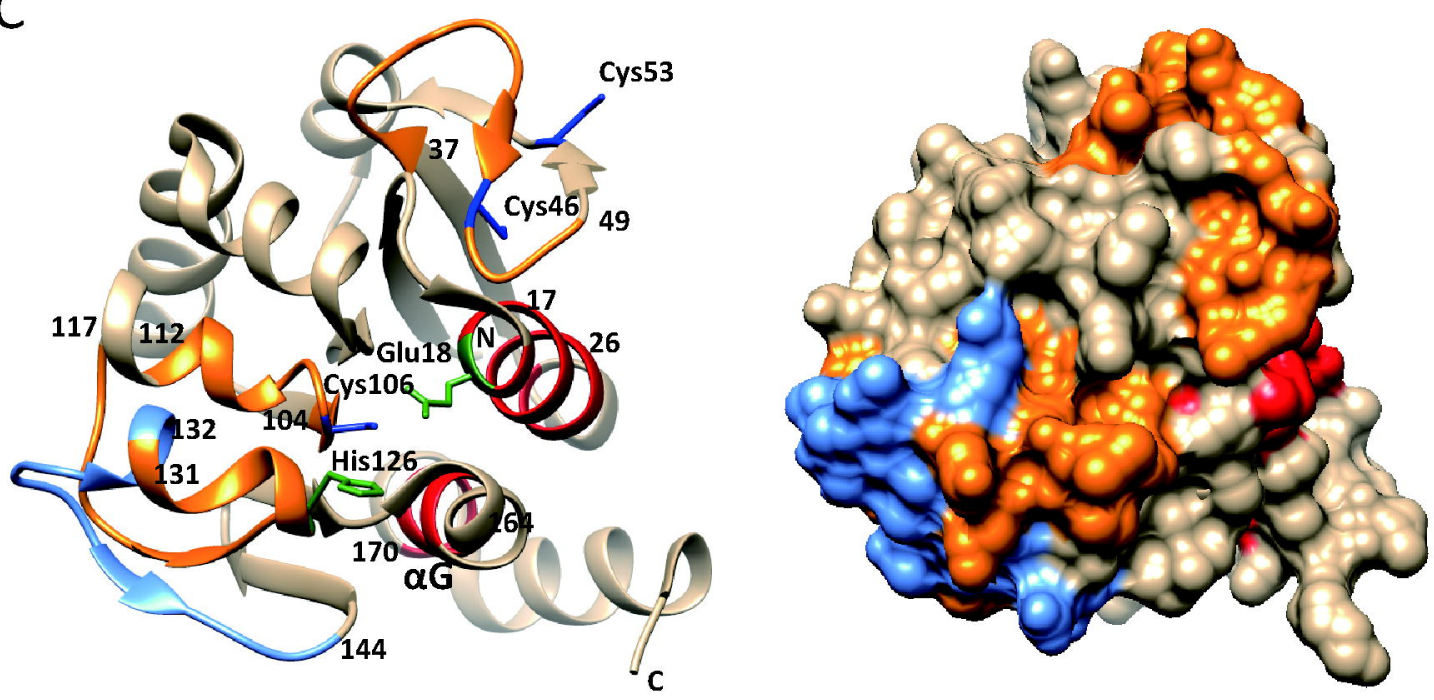

$-30^{\sim}-20(\%)$ $-20 \mathrm{~N}-10(\%)$ $-10 \sim 20(\%)$ 20 30(\%) $30 \sim(\%)$

Figure 4. 
A
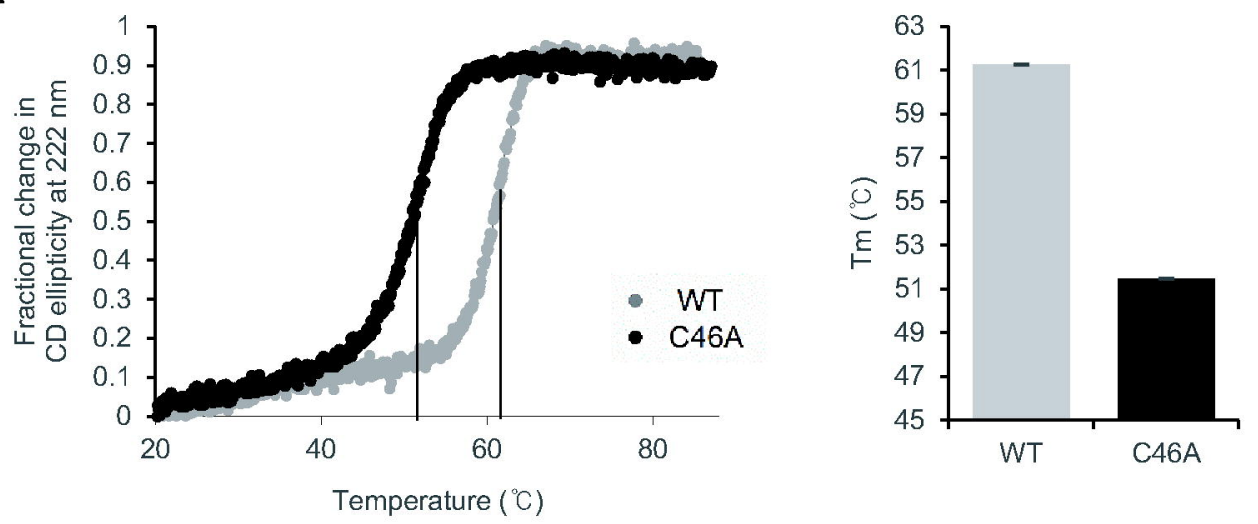

B

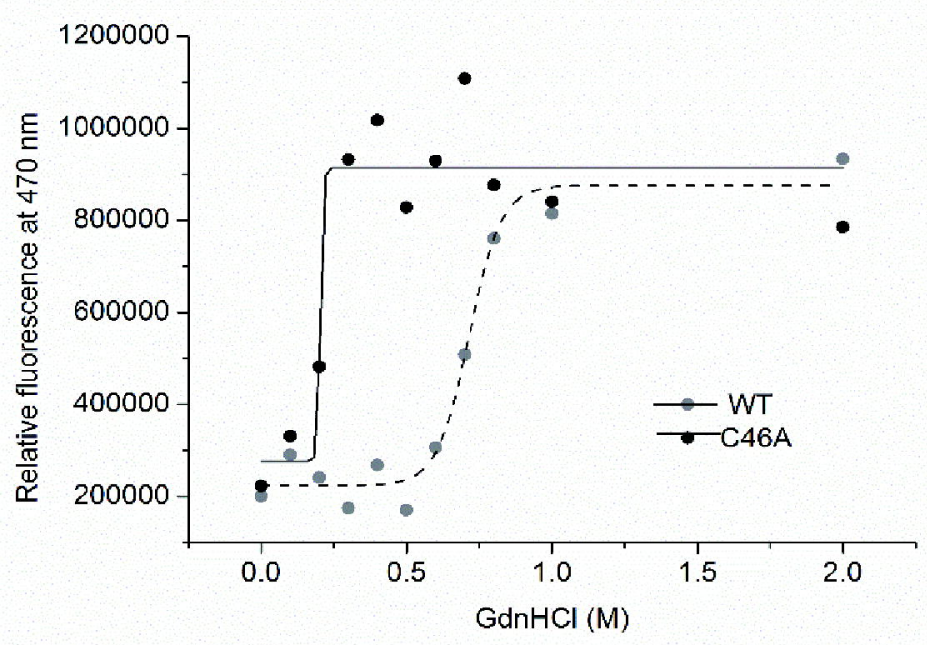

Figure 5. 
A IP : Flag, Silver staining

(-) $\beta-\mathrm{ME}$

$\frac{\text { Flag }}{-++} \frac{\mathrm{WT}}{-++} \frac{\mathrm{C} 46 \mathrm{~A}}{-++} \frac{\mathrm{C} 53 \mathrm{~A}}{-++} \frac{\mathrm{C} 106 \mathrm{~A}}{-+}$

(+) $\beta-M E$

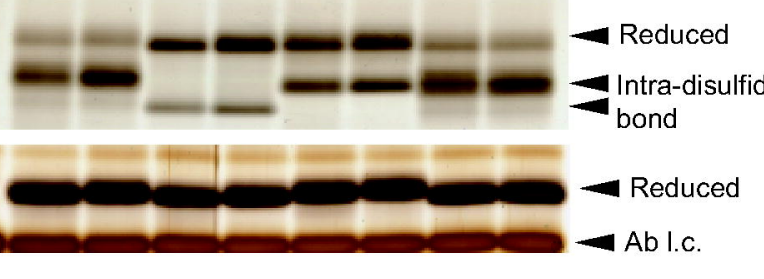

B

IP : Flag, IB : Flag

$\mathrm{H}_{2} \mathrm{O}_{2} \frac{\text { Flag }}{-++} \frac{\mathrm{WT}}{-++} \frac{\mathrm{C} 46 \mathrm{~A}}{-++} \frac{\mathrm{C} 53 \mathrm{~A}}{-+} \frac{\mathrm{C} 106 \mathrm{~A}}{-+}$

(-) $\beta$-ME

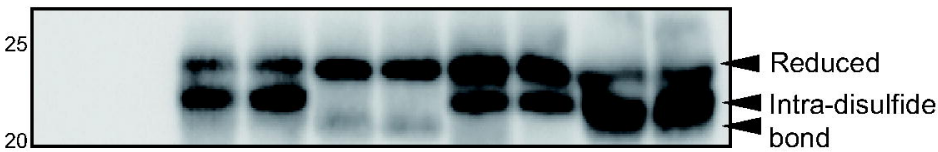

(+) $\beta$-ME

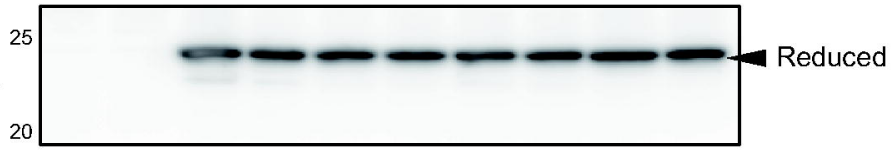

$$
\begin{aligned}
& \text { C } \quad Y: 42 \operatorname{Dpvoc} \mathbf{C R}^{48} \\
& \mathrm{y}: \text { : DVv C PDASLEDAKK }{ }^{63}
\end{aligned}
$$

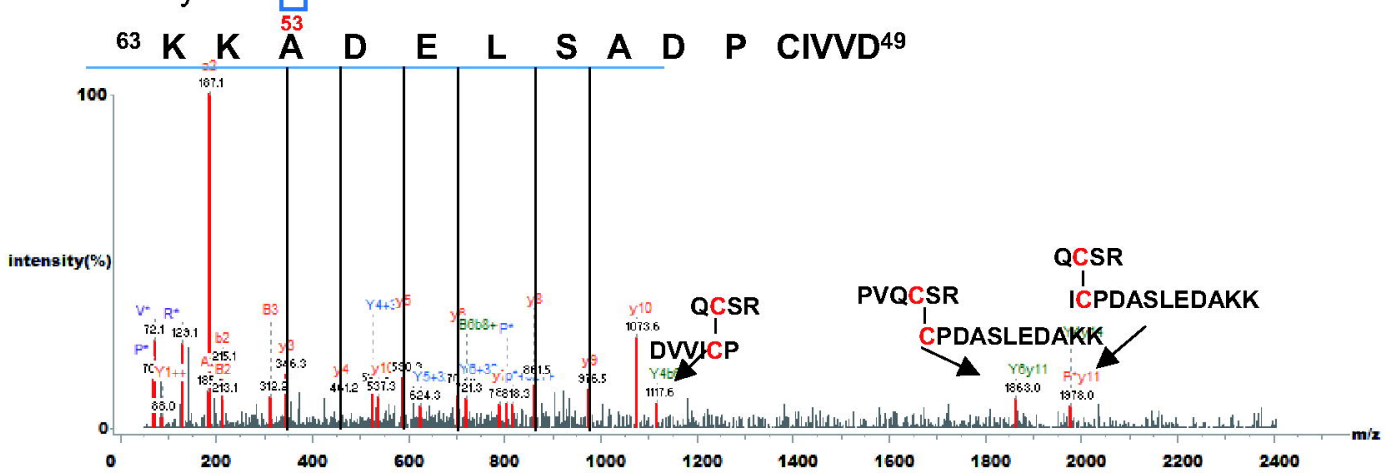

Figure 6. 
A
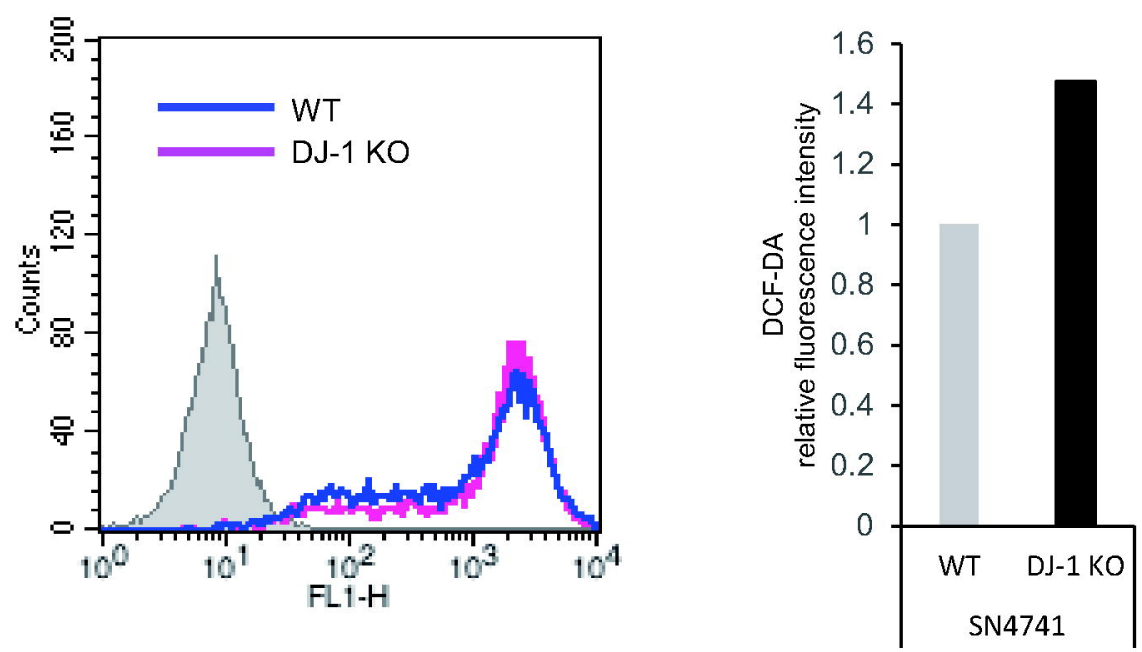

B

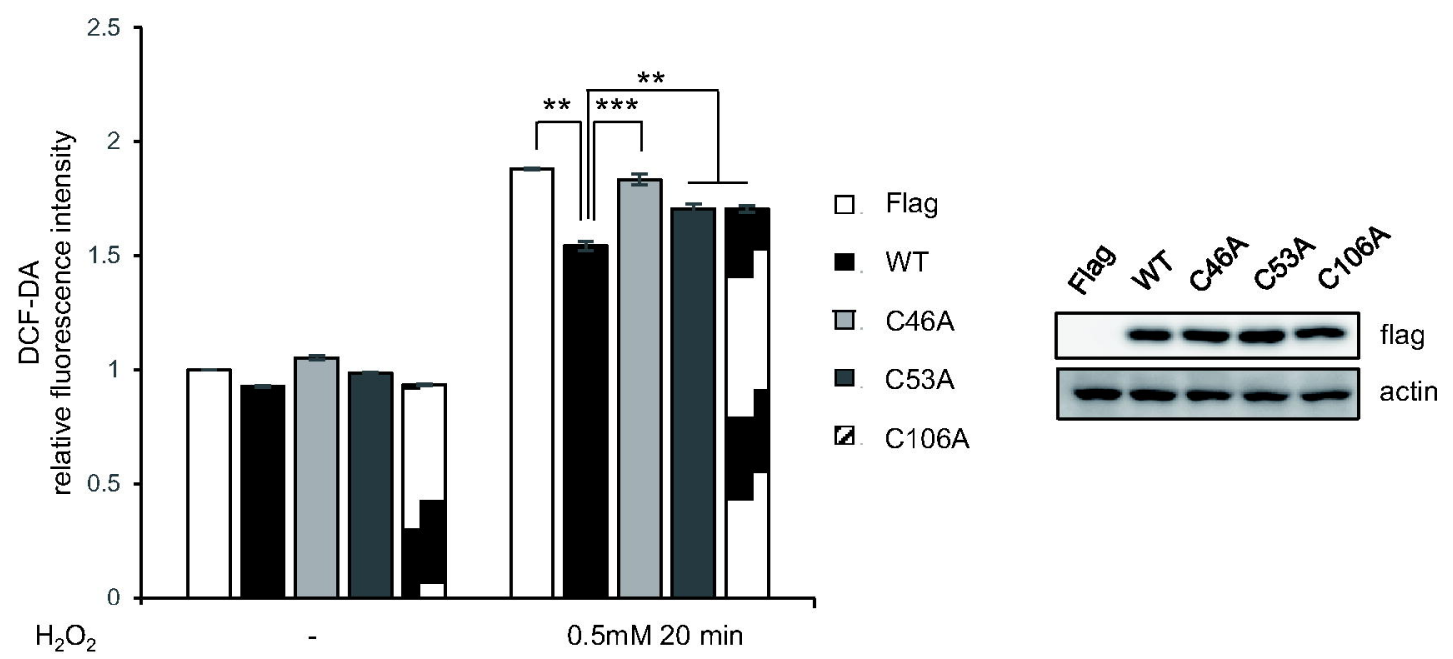

Figure 7. 
A

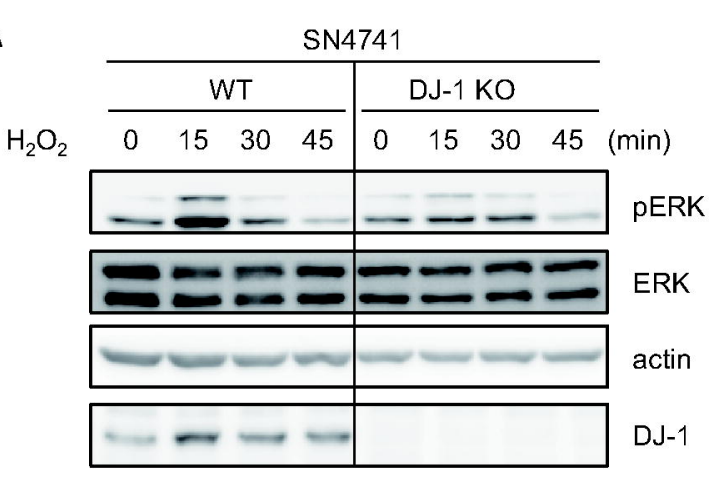

B

DJ-1 KO SN4741
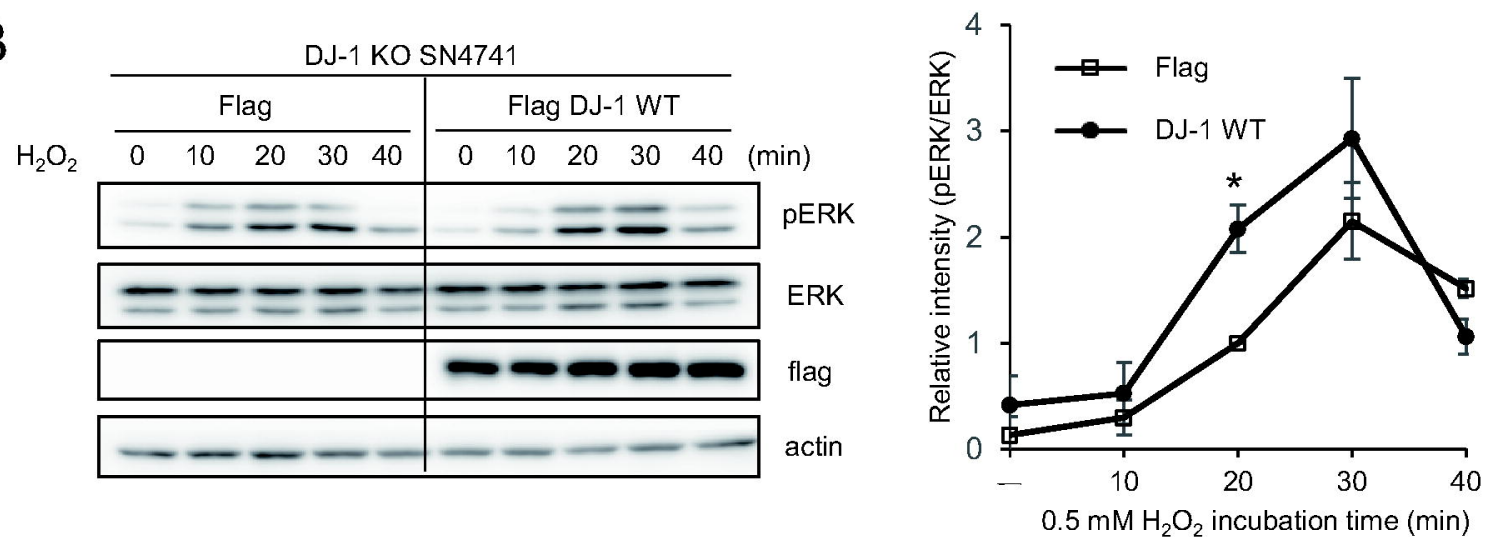

C
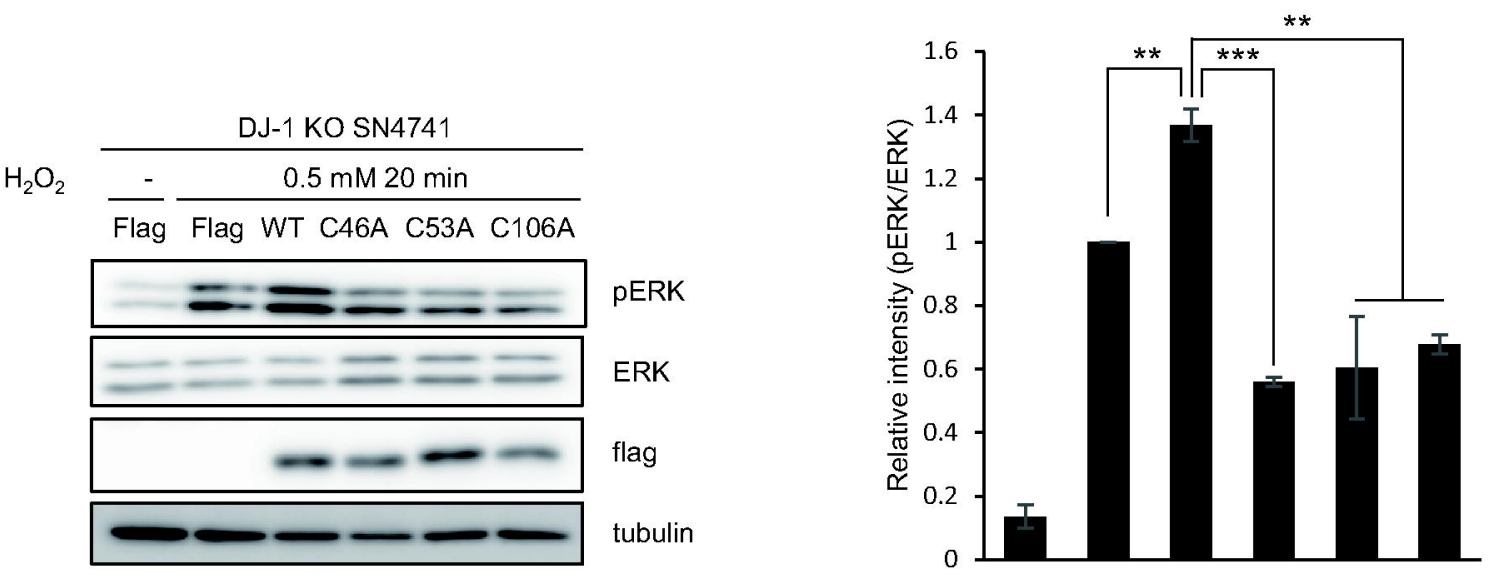

Flag Flag WT C46A C53A C106A $\mathrm{H}_{2} \mathrm{O}_{2} \quad 0.5 \mathrm{mM} 20$ min

Figure 8. 
A
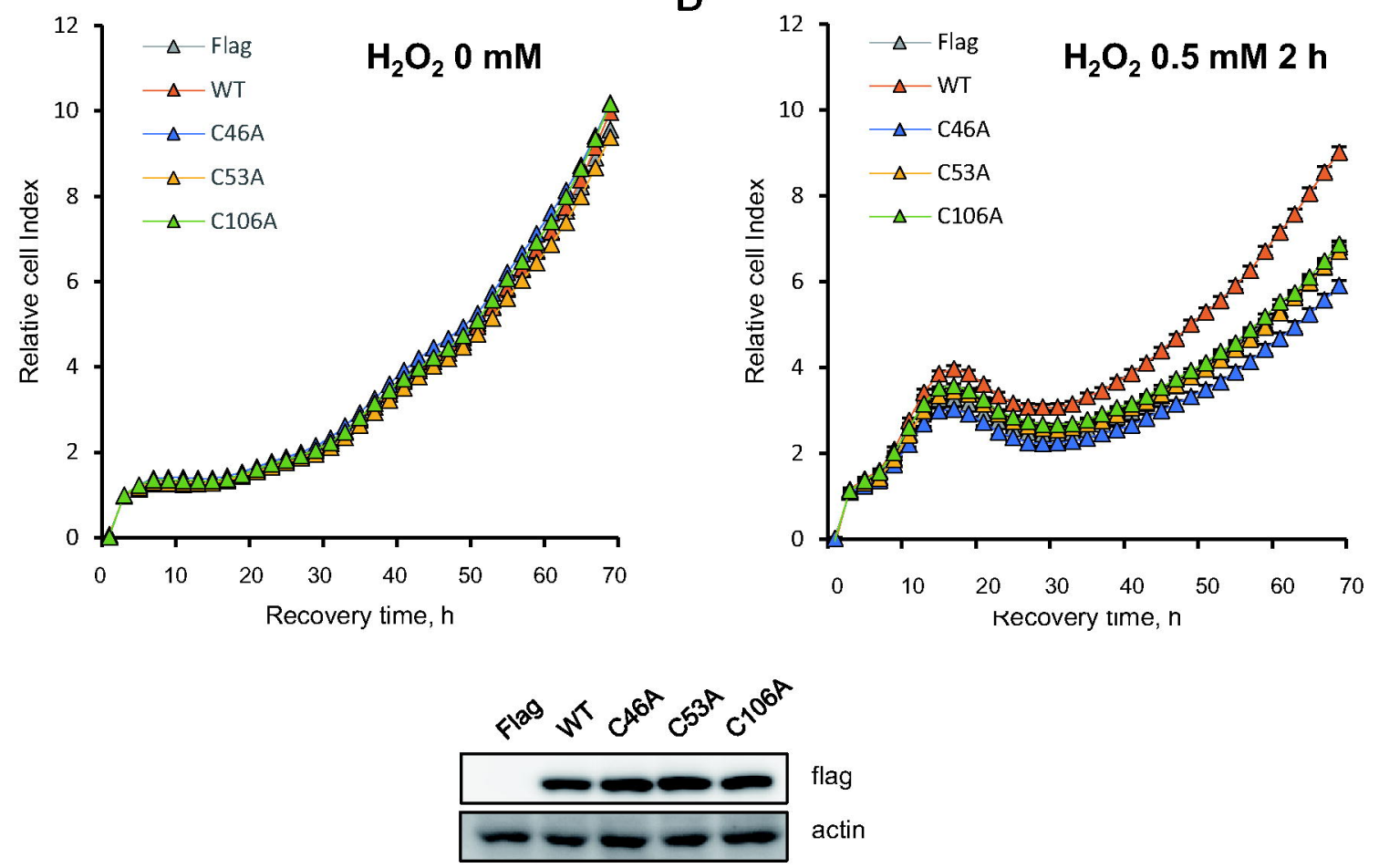

Figure 9. 